\title{
The Status of Radioiodine Control for Nuclear Fuel Reprocessing Plants
}

\author{
L. L. Burger \\ R. D. Scheele
}

July 1983

Prepared for the U.S. Department of Energy under Contract DE-AC06-76RLO 1830

Pacific Northwest Laboratory Operated for the U.S. Department of Energy by Battelle Memorial Institute 


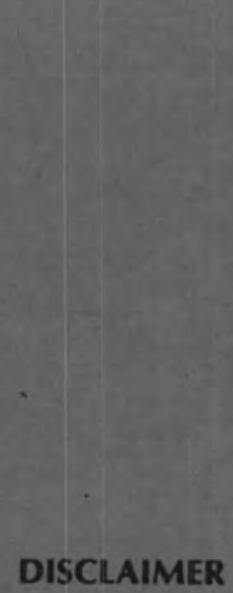

This report was prepared as an account of work spor soled by an agency of the United States Government. Neither the United States Government nor any agency thereof, nor any of their employees, makes any warranty, express or implied, or assumes any legal liability or responsibility ior the accuracy, completeness, or usefulness of any information, apparatu;, product, or process disclosed, or represents that its use would not infringe frivately owned rights. Reference herein to any specific commercial product, process, or service by trade name, trademark, manufacturer, or otherwise, does not necessarily constitute or imply its endorsement, recommendation, or favoring by the United States Government or any agency thereof. The views and opinions of authors expressed herein do not necessarily state or reflyct those of the United States Government or any agency thereof.

\author{
PACIFIC NORTHWEST LABORATDRY \\ operated by \\ BATTELLE \\ for the \\ UNITED STATES DEPARTMENT OF E NERGY \\ under Contract DE-AC06-76RLO $>830$
}


PNL-4689

UC -70

THE STATUS OF RADIOIODINE CONTROL

FOR NUCLEAR FUEL REPROCESSING PLANTS

L. L. Burger

R. D. Scheele

July 1983

Prepared for the

U. S. Department of Energy

Under Contract DE-ACO6-76RL0 1830

Pacific Northwest Laboratory

Richland, Washingt on 99352 
,

-

.  
This report summarizes the status of radioiodine control in a nuclear fuel reprocessing plant with respect to capture, fixation, and disposal. Where possible, we refer the reader to a number of survey documents which have been published in the last four years. We provide updates where necessary. Also discussed are factors which must be considered in developing criteria for iodine control.

For capture from gas streams, silver mordenite and a silver nitrate impregnated silica $\left(A C-6120^{\circledR}\right)$ are considered state-of-the-art and are recommended. Three aqueous scrubbing processes have been demonstrated: Caustic scrubbing is simple but probably will not give an adequate iodine retention by itself. Mercurex (mercuric nitrate-nitric acid scrubbing) has a number of disadvantages including the use of toxic mercury. Iodox (hyperazeotropic nitric acid scrubbing) is effective but employs a very corrosive and hazardous material. Other technologies have been tested but require extensive development.

The waste forms recommended for long-term storage or disposal are silver iodide, the iodates of barium, strontium, or calcium, and silver loaded sorbents, all fixed in cement. Copper iodide in bitumen (asphalt) is a possibility but requires testing. The selection of a specific form will be influenced by the capture process used.

®Trademark of Sud Chemie A.G., Munich, Germany. 

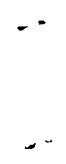

$\therefore$ 


\section{CONTENTS}

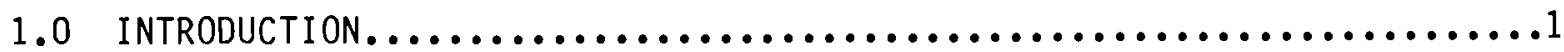

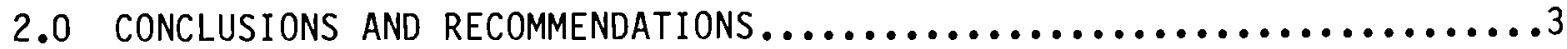

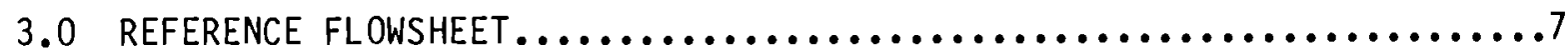

4.0 PROCESSES FOR IODINE CAPTURE $\ldots \ldots \ldots \ldots \ldots \ldots \ldots \ldots \ldots \ldots \ldots \ldots \ldots \ldots$

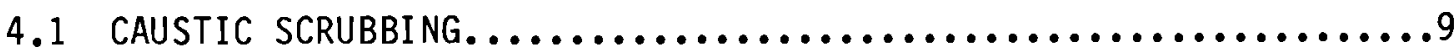

4.1.1 Technical Description............................9

4.1 .2 Efficiency................................

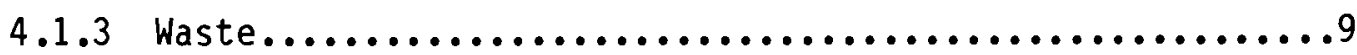

4.1 .5 Advantages................................

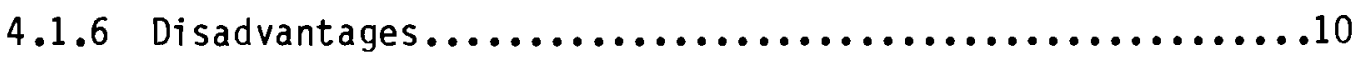

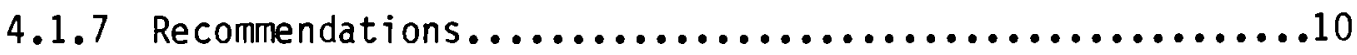

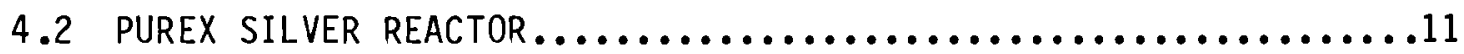

4.2.1 Technical Description........................11

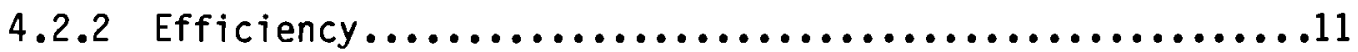

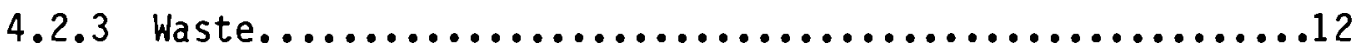

4.2.4 Compatibility with Integrated Off-Gas

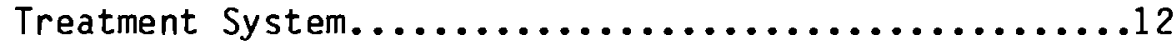

4.2.5 Advantages of Purex Silver Reactor......................

4.2.6 Disadvantages of Purex Si Tver Reactor...............12

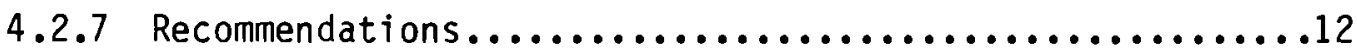

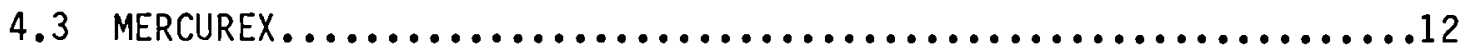

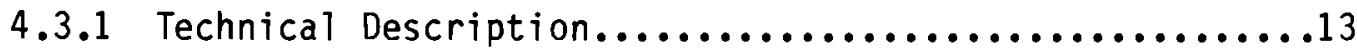

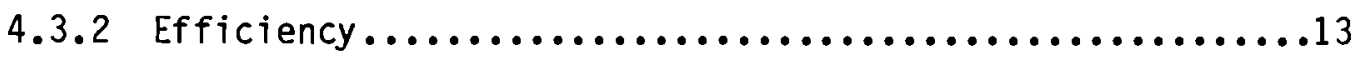

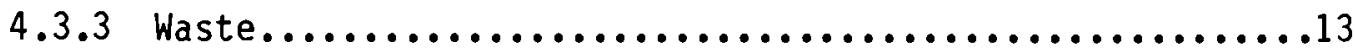


4.3.4 Compatibility with Integrated of:-Gas

Treatment System............................14

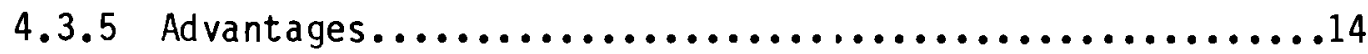

4.3 .6 Disadvantages $\ldots \ldots \ldots \ldots \ldots \ldots \ldots \ldots \ldots \ldots \ldots \ldots \ldots \ldots \ldots \ldots \ldots$

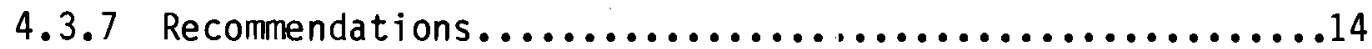

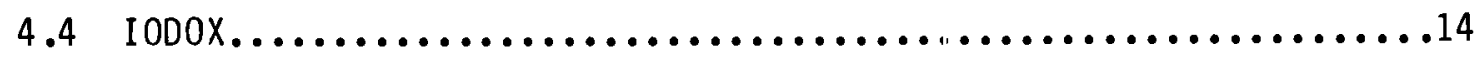

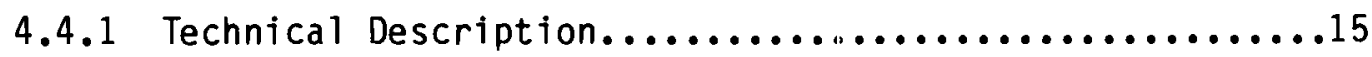

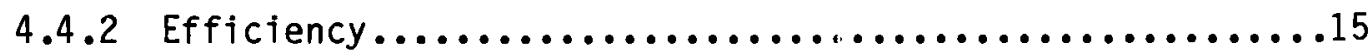

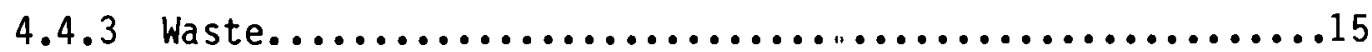

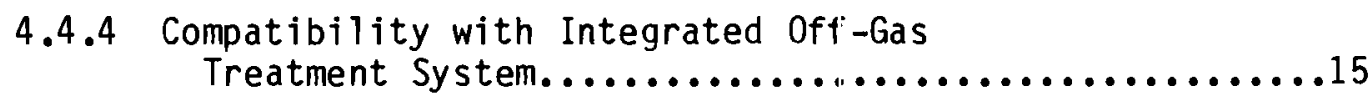

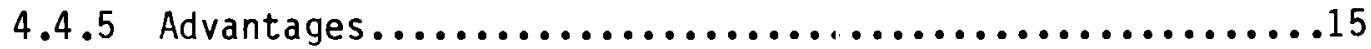

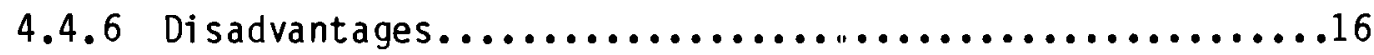

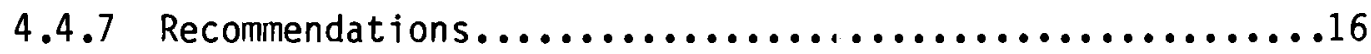

4.5 SILVER ZEOLITES................................

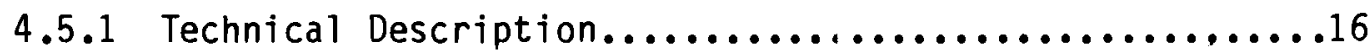

4.5.1.1 Recent Developments....................17

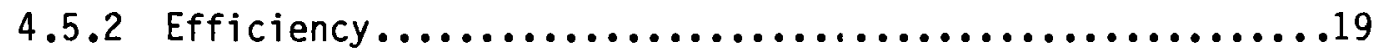

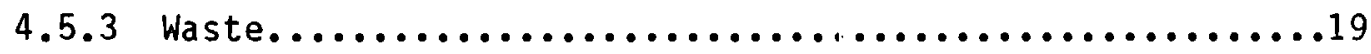

4.5.4 Compatibility with Integrated Off-Gas

Treatment System...........................20

4.5 .5 Advantages...............................20

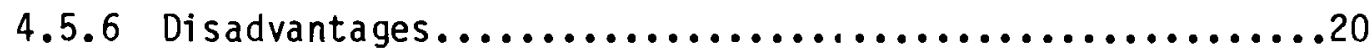

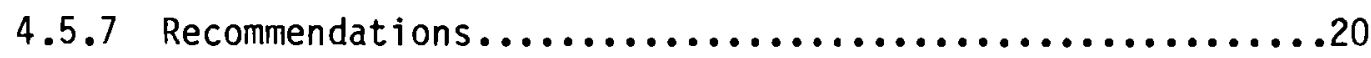

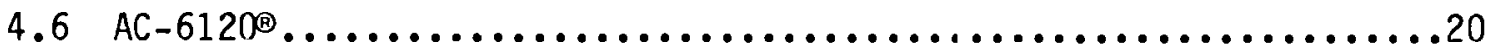

4.6.1 Technical Description..........................21

4.6 .2 Efficiency...............................21

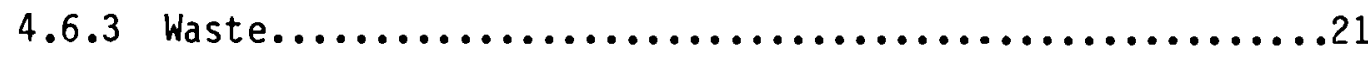


4.6.4 Compatibility with Integrated Off-Gas

Treatment System...........................21

4.6 .5 Advantages.................................22

4.6 .6 Disadvantages..............................22

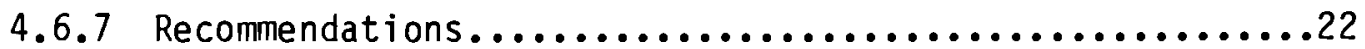

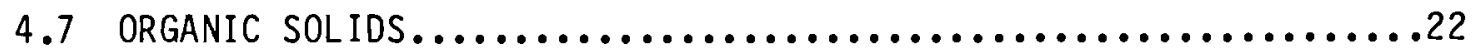

4.7 .1 Technical Description.........................22

4.7 .2 Efficiency................................22

4.7 .3 waste......................................23

4.7.4 Compatibility with Integrated Off-Gas

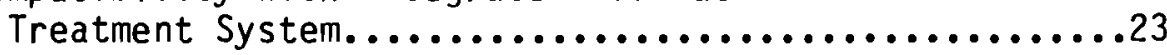

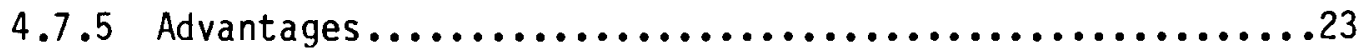

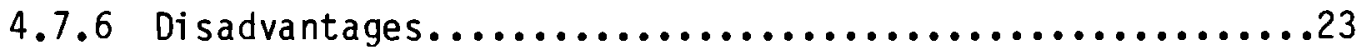

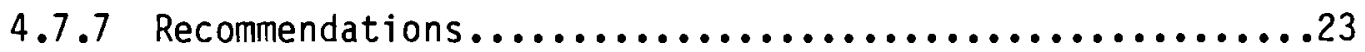

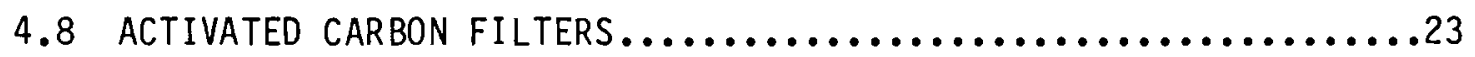

4.8.1 Technical Description..........................23

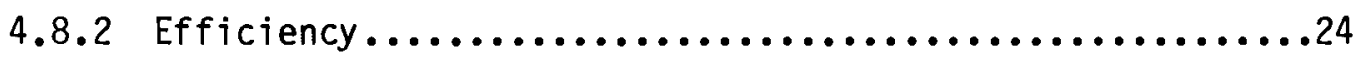

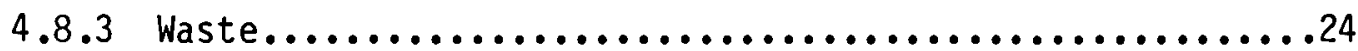

4.8.4 Compatibility with Integrated Off-Gas

Treatment System...........................24

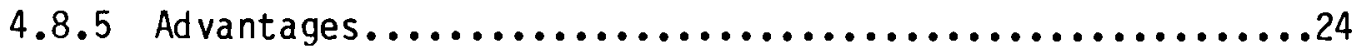

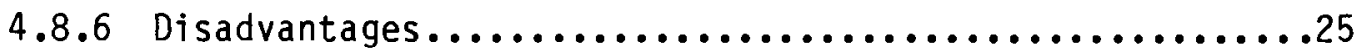

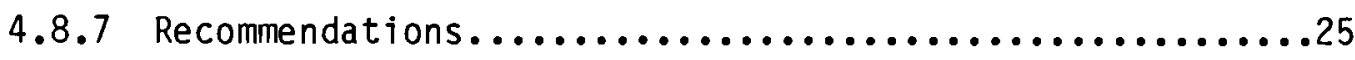

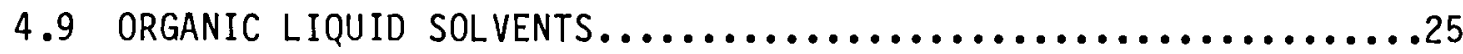

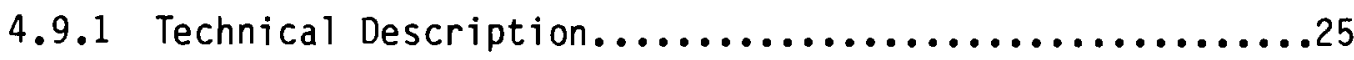

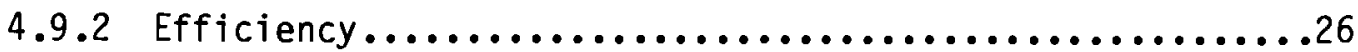

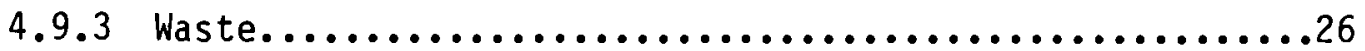

4.9.4 Compatibility with Integrated off-Gas

Treatment System..........................26 
4.9.5 Advantages...................................26

4.9 .6 Disadvantages..............................26

4.9.7 Recommendations..............................26

4.10 ELECTROLYTIC SCRUBBING...........................27

4.10.1 Technical Description.........................27

4.10 .2 Efficiency................................27

4.10 .3 Waste....................................27

4.10.4 Compatibility with Integrated Cff-Gas

Treatment System............................27

4.10 .5 Advantages...............................27

4.10 .6 Disadvantages...............................28

4.10.7 Recommendations............................28

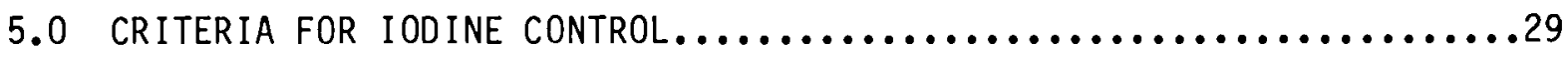

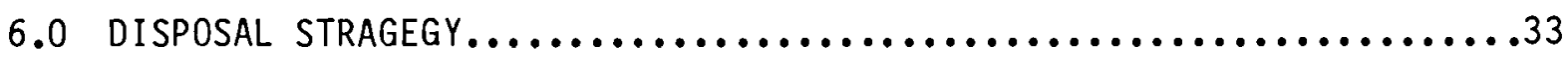

6.1 DISPOSAL OF RECOVERED IODINE $\ldots \ldots \ldots \ldots \ldots \ldots \ldots \ldots \ldots \ldots \ldots \ldots$

6.1.1 Transmutation to Stable Xenon.....................33

6.1.2 Extraterrestrial Disposal.......................33

6.1.3 Ocean Disposal...............................33

6.1.4 Release to Coastal Waters......................33

6.1 .5 Disposal in Rock Formations....................34

6.1.6 Disposal in Clay Formations.....................34

6.1.7 Disposal in Salt Caverns.........................34

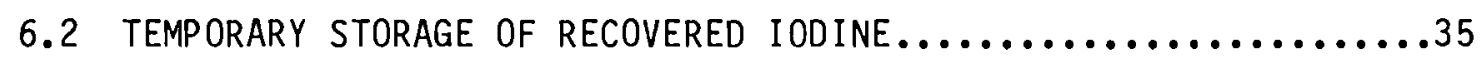

6.3 LONG-TERM CONSIDERATIONS..............................

7.0 METHODS OF FIXATION......................................

7.1 FIXATION COMPOUNDS $\ldots \ldots \ldots \ldots \ldots \ldots \ldots \ldots \ldots \ldots \ldots \ldots \ldots \ldots \ldots . \ldots \ldots$

7.2 SOLIDIFICATION MATRICES $\ldots \ldots \ldots \ldots \ldots \ldots \ldots \ldots \ldots \ldots \ldots \ldots \ldots$

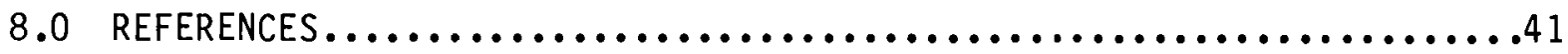




\subsection{INTRODUCTION}

Of the volatile components of nuclear waste, the radioiodines have received the most attention. In particular, ${ }^{129}$ I with its high fission yield and long half-life, has been of concern in fuel cycle considerations. Virtually all the fission product iodine is released from the irradiated fuel at the reprocessing step, and it is here that iodine control must be achieved. The goals are: 1) remove the iodine from the aqueous streams before it becomes dispersed throughout the solvent extraction operations, 2) transfer it to gaseous streams; 3) develop a capture technique that will remove the iodine from the gaseous streams; 4) develop a fixation form that can be easily produced from the capture product and that will ensure safe and effective interim control; 5) develop a final disposal concept, and 6) prevent release to the environment during these operations.

Many reviews and several symposia have dealt exclusively with most of these goals. In addition, there has been considerable input from reactor studies of both normal and accident situations. Both iodine capture (trapping) and fixation have received considerable attention. No consensus has been reached regarding iodine disposal; hence there are no criteria by which to compare disposal concepts. The existing guidelines for release are U.S. Nuclear Regulatory Commission (NRC) (10 CFR 20, 1978) concentration limits; and, indirectly, the Environmental Protection Agency (EPA) (40 CFR 190, 1977) standards for release, $5 \mathrm{mCi} / \mathrm{GWe}-\mathrm{yr}$ for ${ }^{129} \mathrm{I}$, and a recommended maximum thyroid dose of $75 \mathrm{mrem} / \mathrm{yr}$. Thus, although disposal has been considered by several investigators, no extensive studies have been made.

Iodine in the aqueous phases is not specifically considered here since in a "closed" Purex system the aqueous streams are recycled and/or evaporated and all iodine eventually is released to the gas streams. There are, however, available methods for removal of iodine from aqueous streams which have been reviewed by Holladay (1979) and McKay, Miquel and White (1982). Methods of removal of iodine from water to be released to the environment have been studied by Swanson (1978). Other studies have examined the iodine distribution between the gas and aqueous phases in the dissolver off-gas (DOG) scrubber in the fuel reprocessing plant off-gas system (FRP) (Henrich et al. 1980, Henrich and Hufner 1980). 
The reader is referred to the many comprehensive surveys for detailed description of the above topics. Although far from complete, a suggested list is: International Atomic Energy Agency (IAEA) reports 201 (1980) and 209 (1978), Holladay (1979), Jubin (1979), Altomare et al. (1979), Brown, Christian, and Thomas (1983a, 1983b), and McKay, Niquel and White (1982), Nuclear Energy Agency (NEA 1980). A report which considers compatibility of proposed airborne waste systems with regulations has been prepared by Trevorrow et al. (1983) at the Argonne National Laboratory. (1)

The present report is not a summary of technology but rather attempts to examine in capsule form the several concepts for iodine capture, fixation and disposal with regard to 1) feasibility of a sequential operation ending with an acceptable disposal form, 2) compatibility with removal schemes for other airborne waste products, and 3) R\&D required to make the concept more viable.

The iodine fixation study at the Pacific Northwest Laboratory (PNL) began in FY 1977 and initially dealt with both ${ }^{14} \mathrm{C}$ and ${ }^{129} \mathrm{I}$. The program involved a laboratory-scale study of iodine trapping techniques, conversion processes, fixation forms for ${ }^{129} \mathrm{I}$ and ${ }^{14} \mathrm{C}$ and considerations for final disposal. This is the final report of the effort related to ${ }^{129} \mathrm{I}$. The results of the ${ }^{14} \mathrm{C}$ work are discussed in another report (Scheele and Burger 1982). Other reports and papers from the program are cited under references.

(1) Part II, Analysis, is in preparation. 


\subsection{CONCLUSIONS AND RECOMMENDATIONS}

The status of iodine control for nuclear fuel reprocessing has been summarized with respect to capture, fixation, and disposal. Several comprehensive surveys of radioiodine control have been published in the last 4 years. These are cited in the document.

At the present state-of-the-art, silver mordenite (AgZ) beds - two in series - are recommended for iodine removal from gas streams. The German product $A C-6120^{\circledR}$, a silver-containing amorphous silica, can be used in much the same way as AgZ. For small-scale processes there may be little need for any other control. For larger plants, e.g., $5 \mathrm{t} \mathrm{U} /$ day, a preliminary caustic scrub of the dissolver off gas may be desirable. This has the advantage of improving the overall retention of iodine and extending the life of the silver beds by a factor of 10 to 100 . An efficient $N O_{X}$ scrub of the DOG is required for this option. Recycle of silver mordenite beds is not recommended because of operational problems. Other systems recommended for further development for iodine removal are the Freon process (low temperature gas scrubbing), tributyl phosphate (TBP) scrubbing, and Iodox (hyperazeotropic $\mathrm{HNO}_{3}$ scrubbing). Only the latter has been adequately studied. It is a very effective process, but we consider it attractive only if 1 ) the recovered acid can be utilized in the Purex process, i.e., that reconstitution of hyperazeotropic acid is not necessary, and 2) corrosion resistant construction materials are available. Mercurex (mercuric nitrate scrubbing) can also be used as a preliminary iodine trap. It is not recommended because of the toxicity of mercury.

For fixation of the recovered iodine, consideration must be given to the iodine form produced by the recovery process. The ultimate choice will also be influenced by the disposal strategy. Since there are no established criteria for the latter, potential fixation forms have been evaluated on the basis of chemical and physical stability, solubility, toxicity, and cost and availability of materials.

Based on these factors, silver iodide is the preferred fixation form on every count except cost. Cuprous iodide may be satisfactory if it is maintained in a reducing and nonalkaline environment. The iodates are second choices because of their stability and low cost and may be adequate on all 
counts. Iodine-loaded silver mordenite (AgZI) is adequate if the iodine loading is not excessive, e.g., 30 to $40 \%$ of theoretical. Mercury, lead, and thallium compounds are not recommended as they may be more hazardous than the ${ }^{129}$ I. Iodine-containing sodalite was an attractive material in preliminary tests, but unfortunately the preparation process requires extensive development.

Leach testing of sodalite and cements contairing the compounds mentioned above show silver iodide and sodalite to be superior to all the others. The iodates and AgZI mentioned may have adequately low leach rates depending on the disposal strategy selected.

The 16-million year half-life of ${ }^{129}$ I poses unique disposal questions since the absence of major geologic changes cannot be guaranteed over the time of 10 half-lives required for radioactive decay. Secondly, lack of established disposal criteria for ${ }^{129}$ I makes a firm choice impossible. However, it is easily shown that a moderate dispersion of ${ }^{129} \mathrm{I}$ produces both a concentration well below maximum permissible concentrations (mpc) values for water and air, and an isotopic dilution with inactive ${ }^{127}$ I such that there is negligible hazard from ingestion.

With this in mind, the first choices for disposal are the following fixation forms placed in the deep ocean: AgI in cement, selected group II iodates in cement, AgZI in cement, or possibly CuI in bitumen (asphalt). As an alternative disposal option the same materials suitably packaged to retard release by leaching and placed in deep geologic formations would probably be adequate. In either case any radioiodine reaching the biosphere over the long periods of time (ten of millions of years) would likely be diluted to innocuous levels.

Space disposal of ${ }^{129}$ I is considered expensive and too risky at the present. However, it may be a reasonable option after a few decades of development of space technology.

Several areas in need of additional study have been identified:

- Details of the mechanism of iodine loading on silver zeolites could improve silver utilization and also lead to a better storage form for this material. In view of the utility of the zeolites, a R\&D program to obtain some fundamental information is desirable. A potential 
conversion process to recover the silver for reuse has been identified but needs study.

- Processes for conversion of other iodine-capture products to a storage or disposal form also need to be developed. Examples are removal of iodine from Freon or other organic scrubs, removal of iodine from caustic scrubs, and the conversion of the Iodox nitric acid-iodic acid slurry to an insoluble iodate waste form. 



\subsection{REFERENCE FLOWSHEET}

Figure I shows a probable iodine path for a typical reprocessing flowsheet based on the Purex process. It is assumed that no head-end step is in place which would concentrate iodine or other volatile radionuclides prior to fuel dissolution. The small amount of the shear off gas (SOG) and vessel of gas (VOG) are included in the off-gas treatment system (OGTS) but may actually be treated by separate removal systems. The measure of efficiency which we will use in this document is the retention factor (RF), which is the ratio of the amount of iodine introduced to the quantity uncaptured. If the iodine in the high level waste (HLW) and the intermediate level waste (ILW) is released, the overall RF is $\sim 350$. If recovered in subsequent waste handing the RF becomes $\geqslant 10^{3}$.

It is not certain what degree of recovery of the various airborne radionuclides will be required in future fuel cycle operations. Although total release limits are specified for ${ }^{85} \mathrm{Kr}$ and ${ }^{129} \mathrm{I}$, they may be unrealistic. Undoubtedly these, as well as standards for ${ }^{3} \mathrm{H}$ and ${ }^{14} \mathrm{C}$, will be reviewed in a few years. It has been argued that on a dollar per/man-rem-averted basis that on $1 y{ }^{129}$ I needs to be controlled, and that it is cost effective to control $99 \%$ of the iodine but not $99.6 \%$ as required by the EPA release standard (Brown, Christian and Thomas 1983a).

For the present, the reference conditions assume recovery of ${ }^{85} \mathrm{Kr}$ with a retention factor of about 10 to 20 and possibly a needed recovery of ${ }^{14} \mathrm{C}$. On the other hand, it is assumed that all tritium will be released. The discussion assumes an overall retention factor goal of $10^{3}$ for ${ }^{129} \mathrm{I}$. The captured iodine will be fixed in a stable form suitable for interim storage and transportation. This form is further evaluated in terms of final disposal. 
99.71

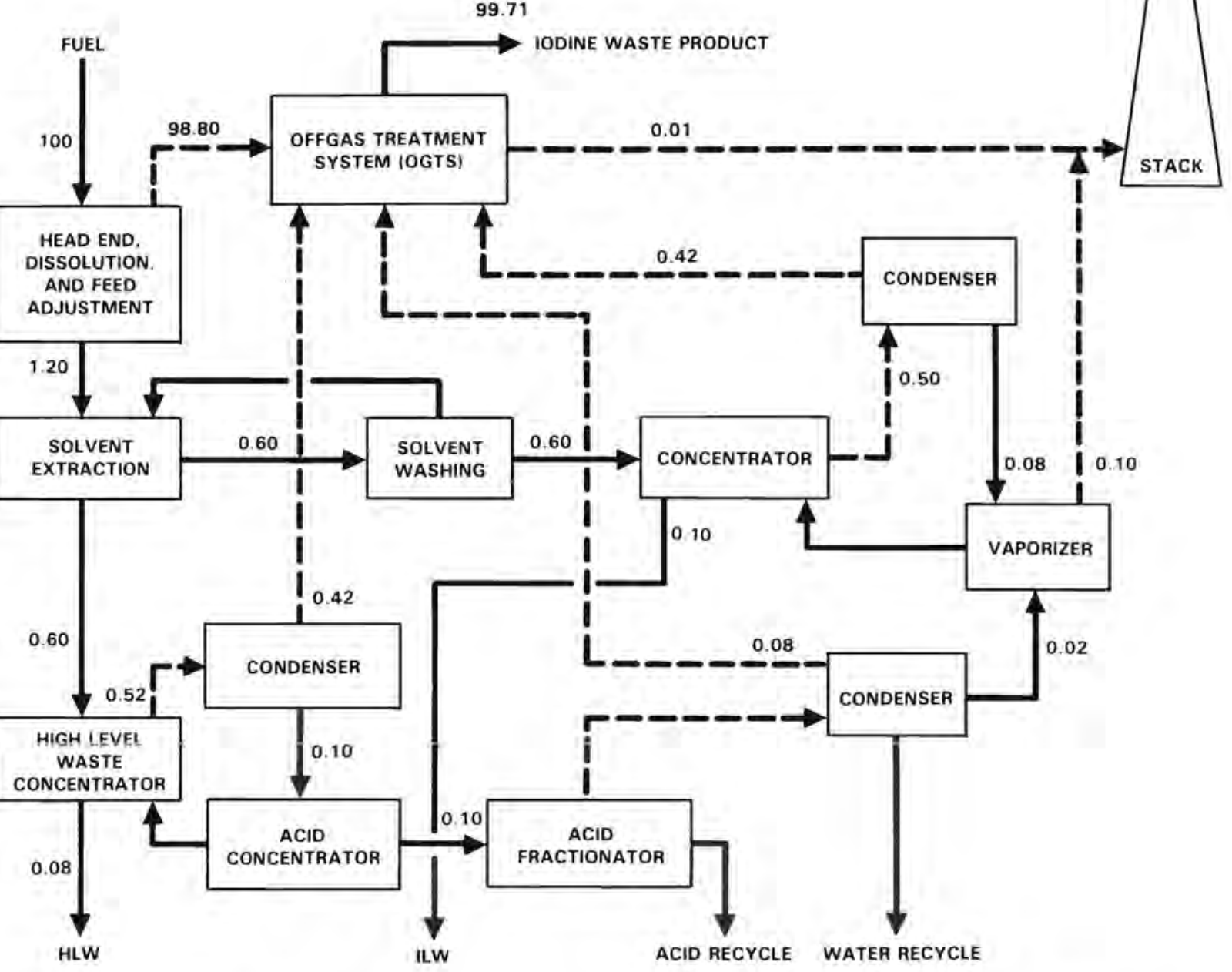

LEGEND

- LIQUID STREAMS

GAS STREAMS

IF THE IODINE IN THE HIGH LEVEL AND INTERMEDIATE LEVEL WASTES

IS RELEASED. THE OVERALL RF IS $\sim 350$. IF RECOVERED IN SUBSEQUEN

FIGURES ARE IN PERCENT

WASTE HANDLING, THE RF IS $\sim 10^{3}$

FIGURE 1. Probable Iodine Path in Typical Fuel Reprocessing Plant 


\subsection{PROCESSES FOR IODINE CAPTURE}

Several technologies have been developed for the removal of radioiodine from gaseous streams in a FRP. These are of two types, liquid scrubbers and solid sorbers.

\subsection{CAUSTIC SCRUBBING}

Caustic scrubbing was probably the first iodine removal process used. The work is not well documented and considerable uncertainty exists concerning the real merit of the process. There is, however, successful operating experience at Windscale, England; LaHague, France; and Tokai-mura, Japan.

\subsubsection{Technical Description}

The caustic scrubbing process uses sodium (or potassium) hydroxide solutions in a packed or bubble-cap column. Other acidic components of the gas stream, e.g., $\mathrm{CO}_{2}$ and $\mathrm{NO}_{2}$, are also removed.

\subsubsection{Efficiency}

RFs ranging from 10 to 1000 have been reported. Caustic scrubbers are effective for removing elemental iodine but are ineffective for organic iodides. Because of this relatively poor net trapping efficiency, caustic scrubbers may be useful primarily for bulk iodine removal and, if a high RF is required, a secondary iodine trapping process would be required. The rather poor reputation of caustic scrubbing for iodine removal may be due partially to the use of impure caustic and/or poor operating control.

\section{1 .3 Waste}

The resultant waste is a hydroxide solution containing nitrite, nitrate, carbonate, iodide, and iodate. Using $1 \mathrm{M} \mathrm{OH}^{-}$as the scrub solution, about 500 $L /$ tonne $U$ will be generated. No process has been developed for recovering the iodine. It would seem reasonable to oxidize all iodine species to iodate or reduce all species to iodide and convert to an insoluble salt.

It is worthwhile to note that ${ }^{14} \mathrm{CO}_{3}^{2-}$ will also be present in solution. If a decision is made to control ${ }^{14} \mathrm{C}$ release, its presence may complicate treatment of the caustic solution. On the other hand, it may be feasible to 
store ${ }^{129} \mathrm{I}$ and ${ }^{14} \mathrm{C}$ together in cement or other mat:rix; this requires a high $\mathrm{pH}$ waste conversion process.

\subsubsection{Compatibility with Integrated Off-Gas Treat:ment System}

$85_{\mathrm{Kr}}$ will pass through the scrubber. $\mathrm{NO}_{2}$ will be removed, but $\mathrm{NO}$ will still be present. Since $\mathrm{NO}_{2}$ will deplete the caustic solution, an efficient ${ }^{N} O_{x}$ scrubber is required for the DOG, but one which permits the $I_{2}$ to remain in the gas stream.

${ }^{14} \mathrm{CO}_{2}$ will be removed with the iodine. Although this may eliminate the need for a ${ }^{14} \mathrm{C}$-specific removal system -- in the eivent ${ }^{14} \mathrm{C}$ is to be retained -it does complicate the waste treatment chemistry. As yet, no process has been suggested which would remove $\mathrm{CO}_{2}$ from the off gas without trapping iodine. If ${ }^{14} \mathrm{C}$ is to be retained and stored with the ${ }^{129} \mathrm{I}$, then conversion steps must operate at a high $\mathrm{pH}$. The alternative is to acidify after conversion of iodine to iodate or iodide and either release the $\mathrm{CO}_{2}$ or recapture it.

\subsubsection{Advantages}

- Elemental iodine is efficiently removed.

- Process is simple and inexpensive.

- ${ }^{14} \mathrm{CO}_{2}$ is also trapped.

- $\mathrm{NO}_{2}$ is also trapped.

- Process requires no special construction materials.

\subsubsection{Disadvantages}

- Organic iodides are not removed.

- No waste treatment process has been developed.

- $\mathrm{CO}_{2}$ trapped could precipitate in sodium system and cause plugging.

- Potential ${ }^{14} \mathrm{C}$ trapping complicates waste treatment.

- If $\mathrm{NO}_{2}$ is not efficiently removed prior to the caustic scrub, then depletion of the caustic occurs, resulting in high waste volumes.

\subsubsection{Recommendations}

- Operational studies could improve removal efficiency of the process. It is likely that some of the early work with caustic scrubbing was not carefully done. Further demonstrations may be worthwhile. 
- Unless there are provisions to store or dispose of liquid wastes, a method for conversion of the $\mathrm{I}^{-}$and $\mathrm{I}_{3}^{-}$to a solid waste form of low leachability is required.

\subsection{PUREX SILVER REACTOR}

Silver nitrate evaporated onto ceramic materials has been used for many years in an attempt to control iodine release. It is usually described as the "silver reactor" (RHO 1980).

\subsubsection{Technical Description}

The process uses ceramic solids such as Intalox saddles which are coated with concentrated silver nitrate solution, and the solution evaporated. The process gas is passed over the material where iodine is trapped as AgI and $\mathrm{AgIO}_{3}$. The temperature control has typically not been very precise, but an attempt is made to keep the temperature in the vicinity of $190^{\circ} \mathrm{C}$. The unit is regenerated by flushing with concentrated $\mathrm{AgNO}_{3}$ solution.

\subsubsection{Efficiency}

The process could perhaps be considered the genesis of the methods involving impregnation of porous materials with silver nitrate such as the use of $A C-6120^{\circledR}$ (Section 4.6), which appears to be much more effective. Although the "silver reactor" is apparently capable of RFs up to $10^{3}$, historically it has operated well below that level, due in part to poor physical characteristics of the bed. For example, if the temperature is too low, condensed acid and water wash off the silver nitrate; if too high, the silver nitrate melts and drains away.

The process is easy to install and with careful control will operate properly. Evoniuk (1981) has recently reviewed the Hanford Purex silver reactor performance and concludes that an average RF of 100 is probably achievable. Whether the system is competitive with other methods depends on the overall RF required, operational control, and decisions regarding disposal. Work by Strachan (1978) suggests that the iodine species formed upon capture was not stable at process and/or storage conditions. Analysis of "silver reactors" which had been used and then stored for several years showed little iodine remaining, and that it had been replaced by chlorine. These 
results suggest that care must be taken to insure that chlorine levels in the FRP are minimized.

\subsubsection{Waste}

Regeneration of the beds is accomplished by resaturating with silver nitrate solution and drying. No other waste treatment has been attempted. The policy has been to bury the depleted reactors when they are no longer effective.

\subsubsection{Compatibility with Integrated Off-Gas Treatment System}

Additional iodine retention may be needed to prevent interference with ${ }^{14} \mathrm{CO}_{2}$ or ${ }^{85} \mathrm{Kr}$ recovery. High $\mathrm{NO}_{2}$ concentrations reduce the efficiency.

\subsubsection{Advantages of Purex Silver Reactor}

- Equipment is simple.

- Operating costs are low (excluding cost of silver).

4.2.6 Disadvantages of Purex Silver Reactor

- Effective operating temperature range is narrow.

- Operating efficiency is typically poor.

- Silver is valuable and expensive.

- Other halogens interfere with iodine retention.

- A waste treatment process has not been developed.

\subsubsection{Recommendations}

The demonstrated poor efficiency of the silver reactor may be due to a large extent to the poor surface characteristics of the material used. It would seem reasonable to replace the coated saddles with a high surface area material which will hold the silver nitrate better. Amorphous silica as employed in $A C-6120^{\circledR}$ (see Section 4.6) is an example.

\subsection{MERCUREX}

The Mercurex process is a gas scrubbing process which uses a mercuric nitrate solution to trap iodine by virtue of the st:rong iodide complexes formed by the $\mathrm{Hg}^{2+} \mathrm{ion}$. It was first proposed and studied by Stromatt (1958) at Hanford. Development work was largely carried out at the Oak Ridge 
National Laboratory (ORNL) and is described by Holladay (1979). The Barnwell FRP is designed to use this process.

\subsubsection{Technical Description}

The process has been tested using both packed and bubble-cap columns. The solution is 0.2 to $0.4 \mathrm{M} \mathrm{Hg}\left(\mathrm{NO}_{3}\right)_{2}$ in nitric acid. Originally dilute acid was employed, 4 to $5 \underline{M}$; later work showed greatly improved organic iodide removal with higher concentrations, e.g., 8-14 M. Adequate contact time is required for oxidation of the organic iodides. Oxides of nitrogen normally present in the gas to be scrubbed prevent the formation of insoluble mercuric iodate. Stable complexes are produced, and the iodine concentration is typically permitted to build up to an $\mathrm{I} / \mathrm{Hg}$ ratio of about 0.25 .

\subsubsection{Efficiency}

The efficiencies for $I_{2}$ removal are very good. RF values of $10^{3}$ to $10^{4}$ have been reported for a wide range of operating parameters. RF values for organic iodides are much lower and depend on gas residence time and concentrations of mercury and $\mathrm{HNO}_{3}$. Using $0.4 \mathrm{M} \mathrm{Hg}\left(\mathrm{NO}_{3}\right)_{2}$ and 10 to $14 \mathrm{M} \mathrm{HNO}_{3}$, good RFs are obtained for alkyl iodides. Aromatic iodides are not effectively removed. An RF value of $10^{2}$ can probably be achieved for routine plant operation using recycled Mercurex solution.

\subsubsection{Waste}

The waste solution contains $\mathrm{Hg}\left(\mathrm{NO}_{3}\right)_{2}$, nitric and nitrous acids, and $\mathrm{Hg}^{2+}$ iodide complexes. At $0.4 \mathrm{M} \mathrm{Hg}^{2+}$ an iodine concentration of about $12 \mathrm{~g} / \mathrm{L}$ can be reached before precipitation of $\mathrm{HgI}_{2}$ occurs. Basically, two approaches for waste handling have been tested: 1) oxidation to $\mathrm{Hg}\left(\mathrm{IO}_{3}\right)_{2}$ which precipates and is separated, and 2) reduction to $\mathrm{Hg}$ metal.

Oxidation by boiling the nitric acid solution was studied at ORNL (Yarbro et al. 1969). Partridge and Bosuego (1979) showed that volatilization of $I_{2}$ during this step could be controlled by properly selecting the acid concentration. PNL work demonstrated that the oxidation could be done electrolytically without $I_{2}$ evolution (Scheele 1978).

Once the iodine has been oxidized, the slurry can be 1) evaporated to dryness, 2) the precipitated $\mathrm{Hg}\left(\mathrm{IO}_{3}\right)_{2}$ can be recovered for disposal or 3) metathesized to precipitate $\mathrm{HgO}$ and form aqueous iodate followed by 
formation of an insoluble iodate such as $\mathrm{Ba}\left(\mathrm{IO}_{3}\right)_{2}$ " The latter has been demonstrated on a bench-scale by Rogers, Moore, and Morgan (1980).

Reduction as developed by Collard and coworkers (1980) uses electrolysis to produce $\mathrm{Hg}$ metal for recycle and converts the iodide to CuI by reaction with $\mathrm{Cu}_{2} \mathrm{O}$ or with $\mathrm{Cu}^{+}$ion produced by hydrazine reduction. The CuI could be a suitable disposal form if the environment is nonalkaline and reducing.

\subsubsection{Compatibility with Integrated Off-Gas Treatment System}

The process is compatible with off-gas treatment systems. $\mathrm{NO}_{x}$, which is normally present, is desirable as it prevents iodcte formation. Other volatile components, such as ${ }^{85} \mathrm{Kr}$ and ${ }^{14} \mathrm{CO}_{2}$, are not removed.

\subsubsection{Advantages}

- Process is tolerant of components in DOG.

- Process is effective for $I_{2}$ and, if high acicity is used, alkyl iodides.

- Process requires no special construction materials.

- Potential corrosion problems exist if high acid scrub is used.

\subsubsection{Disadvantages}

- Practical RFs appear much lower than predicted by laboratory data with fresh solutions.

- Aromatic iodides are not removed.

- No simple waste treatment process has been developed.

- Mercury may be of greater toxicity than the ${ }^{129} \mathrm{I}$.

- Hazardous compounds such as $\mathrm{CH}_{3} \mathrm{NO}_{3}$ may be formed.

\subsubsection{Recommendations}

The complete process, from $\mathrm{I}_{2}$ and organic iodide trapping to waste form production, is still undeveloped. The disadvantages of the Mercurex process appear to outweigh the advantages. Application would be favored by 1) low total iodine to minimize mercury usage, 2) absence of organic iodides (or preaxidation to $I_{2}$ ) so that a low acid scrub could be used, and 3) development of a better waste handling process.

\subsection{I0D0X}

This iodine capture process uses hyperazeotropic nitric acid, $\sim 20$ to $22 \mathrm{M}$, to trap both elemental iodine and organic iodides. It has been given 
the name Iodox, formerly Iodex, by its developers at ORNL. Holladay (1979) provides a detailed description of the process.

\subsubsection{Technical Description}

This process uses the acid as the scrubbing medium in a bubble cap or packed column. The column is usually operated at 60 to $80^{\circ} \mathrm{C}$. All iodine species are converted to iodic acid. The acid is then concentrated in an evaporator, and a stream bled off to further evaporate and precipitate iodic acid as $\mathrm{HI}_{3} \mathrm{O}_{8}$ (or iodine pentoxide $\mathrm{I}_{2} \mathrm{O}_{5}$ ). The recovered nitric acid is either used in other parts of the plant or distilled with $\mathrm{Mg}\left(\mathrm{NO}_{3}\right)_{2}$ to reform the hyperazeotropic acid.

\subsubsection{Efficiency}

Laboratory RFs of $10^{5}$ have been obtained for $\mathrm{I}_{2}$ and $\mathrm{CH}_{3} \mathrm{I}$. The process performed well in the presence of hydrocarbons including aromatics. High concentrations of $\mathrm{NO}_{x}$ and $\mathrm{H}_{2} \mathrm{O}$ in the gas stream are detrimental, although the process has been successfully demonstrated in the presence of $8 \% \mathrm{NO}_{2}$ and $2 \%$ $\mathrm{H}_{2} \mathrm{O}$.

\section{4 .3 Waste}

Following evaporation of the iodine-rich nitric acid to recover the iodine as $\mathrm{HI}_{3} \mathrm{O}_{8}$, the recovered iodine can be converted to an insoluble iodate suitable for disposal. Treatment with barium hydroxide to convert it to barium iodate has been demonstrated by ORNL. The barium iodate thus prepared was then incorporated into cement.

\subsubsection{Compatibility with Integrated Off-Gas Treatment System}

Though $\mathrm{NO}_{2}$ and high humidity can affect the RF, it appears that the process is sufficiently tolerant of $\mathrm{NO}_{x}$ and $\mathrm{H}_{2} \mathrm{O}$ to be effective at conditions expected in an FRP. ${ }^{85} \mathrm{Kr}$ and ${ }^{14} \mathrm{CO}_{2}$ are not removed and their subsequent recovery is not impaired.

\subsubsection{Advantages}

- Process is tolerant of components in DOG. ( $\mathrm{NO}_{x}$ and $\mathrm{H}_{2} \mathrm{O}$ can affect efficiency).

- Process is effective for all iodine species tested.

- No new chemicals are introduced into the FRP.

- Recovered product can be converted to insoluble iodates. 


\subsubsection{Disadvantages}

- Capital costs may be high.

- Process requires special construction materials.

- Process employs a hazardous chemical.

- Special system is required to produce hyperazeotropic $\mathrm{HNO}_{3}$.

Alternatively, the hyperazeotropic $\mathrm{HNO}_{3}$ could be purchased commercially and the recovered acid could be used elsewhere in the FRP, e.g. in fuel dissolution.

- Hazardous compounds such as $\mathrm{CH}_{3} \mathrm{NO}_{3}$ may be formed.

\subsubsection{Recommendations}

Al1 steps from iodine capture to conversion of the iodine to an iodate disposal compound have been demonstrated. The actual concentration of the iodine containing nitric acid, and the precipitation and separation of iodic acid or alternatively conversion of the nitric acid-iodic acid mixture directly to a waste form needs additional work.

The question of nitrated organics and their accumulation to potentially explosive levels needs to be addressed. Zircaloy appears to have been a satisfactory constructional material though further development may be required.

\subsection{SILVER ZEOLITES}

Silver zeolites are zeolites in which the cation, usually sodium, has been partially or completely replaced by silver. Their use for iodine control was first recognized by Maeck, Pence, and Keller (1968) of Idaho National Engineering Laboratory (INEL). Subsequent studies have been performed at INEL, ORNL, and PNL.

Since the writing of the previously cited survey documents, much work has been done on these materials at PNL and ORNL. We have therefore added a discussion on recent developments.

\subsubsection{Technical Description}

Iodine capture by silver zeolites is a dry process which uses granular or pelletized forms of the silver zeolites and relies on the Lewis soft acid and base characteristics of silver and iodine, respectively, to form stable iodine silver complexes or compounds. RFs of $>10^{3}$ have been obtained for both $I_{2}$ and 
$\mathrm{CH}_{3}$ I. Early development used type $X$ silver zeolite ( $\mathrm{AgX}$ ); however, $\mathrm{AgX}$ has poor acid resistance and would suffer in the acidic environment of the FRP. Recent work has emphasized the use of silver mordenite $(\mathrm{AgZ})^{(a)}$, which is $\sim 18$ wt\% silver, prepared from the synthetic sodium mordenite Zeolon ${ }^{\circledR}$ and is resistant to acidic environments.

Five to $20 \mathrm{~cm}$ deep beds of 10 to 20 mesh or $1.6 \mathrm{~mm}$ extrudate are typically used. The bed is operated between 110 and $200^{\circ} \mathrm{C}$ to avoid interference from water absorption; commonly $150^{\circ} \mathrm{C}$ is used. The influent gas stream is preheated before introduction into the bed. Either AgZ or hydrogenpretreated $\mathrm{AgZ}\left(\mathrm{Ag}^{\circ} \mathrm{Z}\right)$ is used. The latter has demonstrated higher loading capacities than the former.

\subsubsection{Recent Developments}

Since the survey documents were issued, work on iodine capture, in particular $\mathrm{CH}_{3} \mathrm{I}$, has been performed at $\mathrm{PNL}$ and $\mathrm{ORNL}$. In addition, recycle of $\mathrm{AgZ}$ and the nature and products of the iodine-AgZ reaction have been studied at PNL.

The PNL work on $\mathrm{CH}_{3} \mathrm{I}$ capture by $\mathrm{Ag}^{\circ} \mathrm{Z}$ (Scheele, Burger and Matsuzaki, 1983) is summarized below:

- A small amount of water e.g., the humidity of normal air $\left(\sim 5 \times 10^{-4}\right.$ $\mathrm{mol} / \mathrm{L})$, is needed in the gas stream for efficient removal of $\mathrm{CH}_{3} \mathrm{I}$.

- Hydrogen pretreatment improves the efficiency of $\mathrm{CH}_{3} \mathrm{I}$ capture.

- Trapping efficiency increases as the zeolite particle size decreases (16 $\mathrm{mm}$ dia extrudate vs 20 to $40 \mathrm{mesh}$ ) and as the gas face velocity decreases (15 vs $3.75 \mathrm{~m} / \mathrm{min}$ ).

- NO (0 to 2 vol \%) is slightly detrimental to iodine loading, but $\mathrm{NO}_{2}(0$ to 2 vol \%) has no effect.

- Improved trapping occurred at $200^{\circ} \mathrm{C}$ compared to $150^{\circ} \mathrm{C}$ and below.

- $\mathrm{CH}_{3} \mathrm{I}$ is catalytically converted to $\mathrm{I}_{2}$ at selected conditions in the presence of nitrogen oxides.

- $\quad A g Z$ and $\mathrm{Ag}^{\circ} \mathrm{Z}$ were effective materials for trapping methyl iodide under conditions expected in a FRP.

(a) Classical literature refers to mordenites which are a high silica content zeolite as AgM, NaM, HM, etc. Nuclear applications have utilized a synthetic mordenite Zeolon ${ }^{\circledR}$, and the symbol $Z$ has been adopted.

(B) Trademark of the Norton Company. 
In the PNL AgZ recycle study, Burger and Scheele (1982b) concluded that AgZ could be recycled using hydrogen reduction at $500^{\circ} \mathrm{C}$ as suggested by Thomas et a 1. (1977). However, a number of difficulties with the process were encountered: corrosion of stainless steel was severe; it was often difficult to strip all the iodine at $500^{\circ} \mathrm{C}$; large releases of $\mathrm{I}_{2}$ occurred during the drying and stripping stages; and the $I_{2}$ released was not effectively trapped by lead zeolite type $X(P b X)$ and therefore circulated back and was captured by the AgZ.

The nature of the iodine-loaded zeolite is discussed in two reports (Burger and Scheele 1982a; Scheele and Burger 198..). These reports give results of studies using solvent extraction, differential scanning calorimetry (DSC), thermogravimetric analysis (TGA), scanning electron microscopy (SEM) coupled with $x$-ray fluorescence elemental analysis, and a brief study using ESCA and Auger spectroscopy. The results are sumnarized below:

- Water influences the degree of reaction and the stability of the products formed from iodine and AgZ.

- If AgZ is loaded beyond $\sim 35 \%$ theoretical capacity, iodine is released upon heating to between 300 and $500^{\circ} \mathrm{C}$.

- The reaction between $\mathrm{I}_{2}$ and $\mathrm{AgZ}$ or $\mathrm{AgX}$ does rot resemble the reaction between simple silver compounds and iodine.

- The SEM work showed that iodine is evenly dispersed throughout the AgZ matrix, but with $\mathrm{Ag}^{\circ} \mathrm{Z}$ it is preferentially atsorbed by silver particles, which are up to $2 \mu \mathrm{m}$ in diameter.

- The formation of AgI is suggested by DSC analyses. In the recent ORNL work (Jubin 1980, 1982) it was found that:

- $\mathrm{Ag}^{\circ} \mathrm{Z}$ is a more efficient trap for $\mathrm{CH}_{3} \mathrm{I}$ than $\mathrm{AgZ}$; loadings up to $127 \mathrm{mg}$ I/g $\mathrm{Ag}^{\circ} \mathrm{Z}$ are possible.

- $\mathrm{CH}_{3} \mathrm{I}$ concentration, and the presence of $\mathrm{NO}$ and $\mathrm{NO}_{2}$ have no effect.

- Moist air up to $2 \times 10^{-3}$ mole $\mathrm{H}_{2} \mathrm{O} / \mathrm{L}$ improves iodine capture.

- Higher temperatures up to $225^{\circ} \mathrm{C}$ improve loading.

- Higher temperatures increase the length of the mass transfer zone; at $150^{\circ} \mathrm{C}$ it was 5 to $7.5 \mathrm{~cm}$; at $200^{\circ} \mathrm{C}$ it was $>10 \mathrm{~cm}$.

- Higher temperatures $\left(200\right.$ to $500^{\circ} \mathrm{C}$ ) and longer exposure time (24 or 48 hours) for reduction by $100 \% \mathrm{H}_{2}$ increase the size of $\mathrm{Ag}$ nodules formed and reduce loading capacity. 
- When using $\mathrm{Ag}^{\circ} \mathrm{Z}$ produced at higher temperatures, higher loadings were reached with glass filter housings than with stainless steel housings.

- Partially exchanged $\mathrm{Ag}^{\circ} \mathrm{Z}$ improved silver utilization.

\subsubsection{Efficiency}

RF's up to $10^{4}$ have been reported for $\mathrm{I}_{2}$ and $\mathrm{CH}_{3} \mathrm{I}$ capture under a variety of operating conditions possible in an FRP. The efficiency is dependent on a number of operational parameters and off-gas constituents mentioned in the previous section. (Thomas et al. 1977; Murphy, Staples, and Thomas 1977; Parker 1979; Jubin 1980; 1982; Scheele, Burger, and Matsuzaki 1983). By proper selection of operational parameters, the negative effects of any off-gas constitutents, with the possible exception of TBP vapor (Parker 1979) or other halogens, can be overcome.

The RF is also dependent upon the iodine loading, decreasing when the iodine content passes the 30 to $40 \%$ theoretical amount (60 to $80 \mathrm{mg} \mathrm{I} / \mathrm{g} \mathrm{AgZ}$ ). Improved silver use, i.e. loadings of theoretical or greater, can be achieved with low RF values. Recent unpublished work by Jubin on partially exchanged $\mathrm{Ag}^{\circ} \mathrm{Z}$ showed improved silver use and is consistent with the above observations.

\subsubsection{Waste}

The product of this process is iodine loaded AgZ, which can be placed in drums or fixed in a solid matrix.

It is possible to remove the iodine from the spent AgZ bed by treatment with hydrogen. This removes the iodine as hydrogen iodide, which can be transferred to an alternative solid sorbent such as lead zeolite $X(\mathrm{PbX})$ for disposal or can be trapped in water, then treated for disposal. Recent work at PNL (Burger and Scheele 1982b) indicates that $\mathrm{PbX}$ is ineffective for capturing all the iodine species released during hydrogen treatment. Lead also presents a toxicity problem if used for a disposal form. Other difficulties were also found, and the hydrogen reduction recycle process does not look attractive.

A potential process for recovering the silver uses a borax-lead oxide flux with a carbon reductant (Morgan et al. 1983). The silver is quantitatively recovered in lead metal, and iodine is retained in the borax glass. Subsequent treatment for the the iodine-containing glass has not been identified. 


\subsubsection{Compatibility with Integrated Off-Gas Treatment System}

Water and $\mathrm{NO}_{\mathrm{x}}$ do not interfere and, as with lodox or Mercurex, the method can be applied directly to the DOG stream. ${ }^{85} \mathrm{Kr}$ and ${ }^{14} \mathrm{CO}_{2}$ are not removed and may be treated normally.

\subsubsection{Advantages}

- Process is effective for all iodine species tested.

- Process is tolerant of components in DOG.

- Process requires no special construction materials.

- Process is simple with low capital costs.

- Process produces a stable and safe waste product.

\subsubsection{Disadvantages}

- Silver is valuable and expensive.

- Other halogens interfere with iodine retention.

- Mechanism of iodine sorption is not completely understood.

- Recycle by hydrogen reduction would require additional development. Other silver recovery methods are not developed.

- TBP vapor interferes with iodine sorption.

\subsubsection{Recommendations}

Several studies evaluating AgZ for capture of iodine have been performed, and general effects have been identified; however, the optimal operating conditions have not yet been identified nor has the basic chemistry of the capture process been adequately studied. The need for basic studies is emphasized by the fact that differing results from iodine capture under similar conditions have been reported by the various workers who have studied this process. Additional work is suggested in these two areas to improve silver use and to develop a more stable waste product.

\section{$4.6 \quad{ }^{A C-6120}{ }^{\circledR}$}

Amorphous silica impregnated with silver nitrate was developed by workers in the Federal Republic of Germany (FRG) for capturing gaseous iodine species found in the gas streams of an FRP. This material is commercially developed by Bayer-Leverkusen of FRG and marketed under the t:rade name AC-6120.(B) 


\subsubsection{Technical Description}

The use of $A C-6120^{\circledR}$ is similar as for silver zeolites. $A C-6120^{\circledR}$ is available as small beads containing 7 and 12 wt\% silver. The bed is operated at an elevated temperature, 110 to $160^{\circ} \mathrm{C}$. The process relies on chemical reactions between silver nitrate and the iodine species to form silver iodide. Two beds in series will be used to insure the necessary RF. Furrer, Kaempffer, and Wilhelm (1982) give the most recent description of work on this process.

\subsubsection{Efficiency}

Furrer, Kaempffer, and Wilhelm (1982) report RFs $>10^{4}$ for total iodine in their tests at the (WAK) demonstration FRP and for elemental iodine at the prototype dissolver off-gas filter test facility (PASSAT). In both, iodine loadings of $95 \%$ silver utilization were achieved. In the latter case, a $60 \%$ silver utilization was achieved before the RF began dropping from a level of $10^{5}$. McKay, Miquel, and White (1982) reviewed the work with AC-6120® and reported similar results for a single bed at WAK. They also mention that tests on alkyl and aromatic iodides showed that alkyl, benzyl, and cyclohexyliodide are trapped, but phenyl iodide is not.

\subsubsection{Waste}

The waste form obtained from the process is the iodine loaded AC-6120 itself. Presumably the iodine is present as silver iodide, though recent work using differential scanning calorimetry (Burger and Scheele 1982a) casts some doubt on this assumption. The spent material is easily handled and is free flowing. Unlike the silver zeolites, $A C-6120^{\circledR}$ cannot be regenerated; but like the zeolites, the silver could be recovered, if required, and the iodine retrapped. A possible scheme was described in Section 4.5.3.

\subsubsection{Compatibility with Integrated Off-Gas Treatment System}

The process is compatible with off-gas treatment systems. $\mathrm{NO}_{2}$ has been found to be beneficial to iodine capture, presumably by reacting with reduced silver to form silver nitrate. Thus, it is generally compatible with the $\mathrm{NO}_{x}$ in the off gas. Excess $N O$ is not desired at it tends to reduce the silver to the metal. The other volatile components ${ }^{85} \mathrm{Kr}$ and ${ }^{14} \mathrm{CO}_{2}$ are not removed. 


\subsubsection{Advantages}

- Process is effective for all iodine species tested.

- Process is tolerant of components in DOG.

- Process requires no special construction materials.

- Process is simple with low capital costs.

- Process produces a stable and safe waste procuct.

\subsubsection{Disadvantages}

- Silver is valuable and expensive. Silver recovery methods have not been developed.

- Other halogens interfere with iodine retention.

- Potential interference may occur from TBP.

- Hazardous compounds such as $\mathrm{CH}_{3} \mathrm{NO}_{3}$ may be formed.

\subsubsection{Recommendations}

This process has been demonstrated in a Purex type pilot plant. Little additional work on development of the process appears necessary. Studies to define the basic chemistry of the process should be performed, as well as studies to determine the effects of tributyl phosphate on iodine removal.

\subsection{ORGANIC SOLIDS}

The obvious solubility of molecular iodine in organic polymers has prompted some study of organic solids for iodine removal. As a class, they are relatively poor compared to other systems. However, a few materials, e.g., the macroreticular resins, show some promise.

\subsubsection{Technical Description}

The Amberlite resins XAD-4 and XAD-12 were shown by Moore and Howerton (1971) to be effective. They were used in packed beds of $5 \mathrm{~cm}$ thickness at ambient temperatures. Jubin (1979) and Holladay (1979) have reviewed the application of macroreticular resins.

\subsubsection{Efficiency}

RF's of $10^{4}$ have been demonstrated in the laboratory for both $\mathrm{I}_{2}$ and $\mathrm{CH}_{3} \mathrm{I}$. Elevated temperatures $\left(100^{\circ} \mathrm{C}\right)$ and high humidities decreased the performance. 


\subsubsection{Waste}

Although these resins are relatively stable for organic materials, they are not suitable for long-term storage. In addition, they will lose iodine if heated. No conversion process to a fixation form has been reported.

\subsubsection{Compatibility with Integrated Off-Gas Treatment System}

The resins probably have adequate resistance to $\mathrm{NO}_{\mathrm{X}}$. No holdup of ${ }^{85} \mathrm{Kr}$ or ${ }^{14} \mathrm{CO}_{2}$ is expected.

\subsubsection{Advantages}

- Many of the resins are tolerant of components in DOG.

- Resins have potentially high iodine capacity .

- Process is simple and inexpensive.

\subsubsection{Disadvantages}

- Iodine is not firmly held.

- Resins are combustible.

- Radiation stabilities have not been adequately demonstrated.

- Studies are incomplete.

- No waste treatment process has been developed.

\subsubsection{Recommendations}

These materials may have specific application since the use is simple and inexpensive. Scaled-up studies would be required. Treatment or long-term management of the loaded resin will have to be considered. Further advantages might have to be uncovered for them to compete with other solid sorbents.

\subsection{ACTIVATED CARBON FILTERS}

Activated charcoal was the first and most universally used sorbent for adsorption of radioiodine. Often it is impregnated with additives to improve performance. Presently it is largely used for ${ }^{131}$ I (and krypton) control at reactors.

\subsubsection{Technical Description}

Charcoal made from a variety of materials including nut shells, wood, coal, and petroleum is activated by heating in steam which expands it and removes volatile organic compounds. It may be used as prepared or impregnated 
with $\mathrm{KI}, \mathrm{I}_{2}-\mathrm{KI}, \mathrm{KOH}-\mathrm{I}_{2}$ or organic amines. It is used in shallow beds under ambient conditions. On pure charcoal, iodine is trapped primarily by physical adsorption. When additives are used, and with other iodine compounds, the chemistry gets complex. Aging effects and impurities further complicate the behavior. It sometimes appears as though the use of charcoal filters is as much an art as a science. However, many years of operating experience have provided effective modes of use. Because of combustion hazards, charcoal filters are not normally employed in FRPs.

\subsubsection{Efficiency}

The efficiency is highly variable depending on the iodine compounds to be trapped, the concentrations, flow rates, humidity: temperature, impregnants used, and the age and weathering of charcoal. RF values may range from $>10^{3}$ to 10 or less. Impregnation with $\mathrm{I}^{-}$or $\mathrm{I}_{\overline{3}}$ improves both the RF and capacity. Organic iodides are not effectively removed at high humidities with plain charcoal. Addition of organic amines such as triethylene diamine (TEDA) greatly improves retention of organic iodides. Holladay (1979) and Jubin (1979) review the behavior of charcoal in iodine sorption. For high efficiency operation, the iodine loadings must be kept low, a few $\mathrm{mg} / \mathrm{g}$ of carbon.

\subsubsection{Waste}

Since charcoal has been extensively used only for ${ }^{131_{I}}$ removal, discharged filters can be stored until the iodine has decayed. Little consideration has been given to waste form handling. Charcoal would not be an adequate storage form for ${ }^{129} \mathrm{I}$, and no conversion methods have been proposed.

\subsubsection{Compatibility with Integrated Off-Gas Treatment System}

Activated charcoal is not very specific as an adsorber. It is anticipated that it would be less than ideal for use for any multicomponent gas stream. It is not possible to use it where $\mathrm{NO}_{x}$ is present because of spontaneous combustion.

\subsubsection{Advantages}

- Process is simple and inexpensive.

- Properly designed filter is effective for $I_{2}$ and organic iodide. 


\subsubsection{Disadvantages}

- Process is intolerant of components in DOG. Oxidants such as $\mathrm{NO}_{2}$ must be absent.

- Charcoal is Combustible. Temperature must be kept below about $190^{\circ} \mathrm{C}$.

- Iodine is not firmly held.

- Material tends to age and lose efficiency.

- Charcoal has poor efficiency in high humidities.

- No waste treatment process has been developed.

\subsubsection{Recommendations}

Much literature has been published on the use and behavior of charcoal filters. Yet, it is apparent that the behavior is not always understood. Most of the work has been empirical. It is likely that more attention to the basic questions, e.g., the physical chemistry of charcoal surfaces, might be useful. However, we see little use for these materials in FRPs.

\subsection{ORGANIC LIQUID SOLVENTS}

The high solubility of $\mathrm{I}_{2}$ and organic iodides in organic solvents has prompted consideration of organic liquids as scrubbing agents. The fluorocarbon process(a) devised for krypton capture also removes iodine, which can be isolated by distillation. A second material examined briefly at PNL is tributyl phosphate (TBP) (Bray and Richardson 1983).

\subsubsection{Technical Description}

Countercurrent columns are suitable for gas scrubbing with organics. Freon $12\left(\mathrm{CF}_{2} \mathrm{Cl}_{2}\right)$ has a low boiling point, $-29.2^{\circ} \mathrm{C}$, and reduced temperature must be employed. TBP may be used under ambient conditions. Iodine can be removed from both solvents by distillation, as can the organic iodides, although the latter has not been demonstrated. Chemical stripping can also be used and might be the choice with TBP where the iodine is more strongly held.

(a) The solvent $\mathrm{CCl}_{2} \mathrm{~F}_{2}$ is not a true fluorocarbon, i.e., with completely substituted fluorine atoms, but rather one of a general class of chlorofluoro-hydrocarbons first described by E. I. DuPont de Nemours \& Co., Inc. as Freons. 


\subsubsection{Efficiency}

RFs of $10^{4}$ for $\mathrm{I}_{2}$ and organic iodides are reported for Freon 12 . The limit is fixed by the contact time and the partial pressure of the iodine compound, i.e., the temperature. RF values have not been reported for TBP. Methyl iodide is not efficiently trapped by TBP or other organic solvents unless the temperature is reduced below ambient.

\subsubsection{Waste}

No chemical change occurs on trapping. Removal from the solvents and conversion to fixation forms have not been demonstrated.

\subsubsection{Compatibility with Integrated Off-Gas Treatment System}

Depending on the temperature, $\mathrm{Xe}, \mathrm{NO}_{2}, \mathrm{CO}_{2}, \mathrm{Kr}, \mathrm{I}_{2}$, and organic iodides will be trapped. NO should not be trapped at normal operating temperature; however, some can be removed when $\mathrm{NO}_{2}$ is present. $\mathrm{Xe}, \mathrm{CO}_{2}$, and $\mathrm{Kr}$ are more volatile and $\mathrm{NO}_{2}, \mathrm{I}_{2}$, and organic iodides less volatile than Freon-12. In principle, a separation by distillation can be achieved. $\mathrm{CO}_{2}, \mathrm{Xe}$, and $\mathrm{Kr}$ can be separated with molecular sieves. Chemical processing of the high boiling residues will be required.

\subsubsection{Advantages}

- Process is effective for all iodine species tested.

- Process is tolerant of components in DOG.

- Process employ chemically resistant materials.

- Materials are nontoxic with minimum safety hazards.

\subsubsection{Disadvantages}

- Low temperatures and/or elevated pressures are required for Freon process.

- Poor $\mathrm{CH}_{3} \mathrm{I}$ recovery for TBP process unless low temperature is used.

- No waste treatment process has been developed.

\subsubsection{Recommendations}

To obtain a high RF, the partial pressure of $I_{2}$ must be kept low. This can be accomplished by low temperatures or by using a solvent that strongly interacts with the iodine. An example of each was cited here. It is probably worthwhile to systematically evaluate these two ex:remes to judge the relative merits and determine potential applications. 
Methods for stripping the iodine from the solvent need to be examined.

\subsection{ELECTROLYTIC SCRUBBING}

This process is based on electrolytic production of oxidants in an aqueous solution while the gas is being scrubbed.

\subsubsection{Technical Description}

The process has been tested on a laboratory scale by employing electrodes in a vertical tube through which the gas is passed (Mailen and Horner 1975). For the electrolyte, dilute nitric acid containing cobalt ion gave the best results.

\subsubsection{Efficiency}

RFs of 100 to 600 for $\mathrm{I}_{2}$ and 5 to 200 for $\mathrm{CH}_{3} \mathrm{I}$ were found in a laboratory apparatus. Insufficient information is available to determine a practical efficiency.

\subsubsection{Waste}

The iodine is oxidized to the +5 state as with the Iodox process. A suggested secondary treatment involves concentration of the solution to precipitate an iodate. In addition, the intermediate oxidant in the case examined, cobalt, will also precipitate. Conversion beyond this concentration state has not been demonstrated.

\subsubsection{Compatibility with Integrated Off-Gas Treatment System}

The product is similar to that formed in Iodox. No compatibility problems are anticipated.

\subsubsection{Advantages}

- Process is effective for $\mathrm{I}_{2}$ and $\mathrm{CH}_{3} \mathrm{I}$.

- Process is tolerant of components in DOG.

- Process operates at low acid concentration.

\subsubsection{Disadvantages}

- Effective organic iodide removal requires catalyst.

- Studies are incomplete.

- No waste treatment process has been developed. 


\subsubsection{Recommendations}

Extensive development is required before the process becomes commercially applicable. It is listed here primarily to emphasize a point: electrons are the only reagents that do not add to chemical wasties and thus electrolytic processes should be examined wherever a potential application is seen. 


\subsection{CRITERIA FOR IODINE CONTROL}

The goal of iodine-129 management is to protect man from unacceptable radiation risks. The underlying basis for criteria development is the radiobiological impact which is discussed in many of the general reference papers cited in the introduction of this report as by well as White and Smith (1982); and Brown, Christian, and Thomas (1983a, 1983b). J. K. Soldat (1983) has recently authored an NCRP report on the evaluation of releases resulting from nuclear power generation. Some basic considerations for setting criteria for disposal of ${ }^{129}$ I were examined in a previous report (Burger 1980). The following discusses the impact of selected iodine releases and control strategies.

In a recent report Brown, Christian, and Thomas (1983b) discuss the requirements for iodine control at an RFP. Their calculations show that total release of the iodine at a 1500 tonne/yr RFP, about $45 \mathrm{Ci} / \mathrm{yr}$, would result in excessive dosage to a maximum exposed individual at $2.4 \mathrm{~km}$ from the source. Thus, uncontrolled iodine release is unacceptable. However, recovering $96.3 \%$ of the iodine ( $R F=27$ ) would reduce the dosage to the $75 \mathrm{mrem} / \mathrm{yr}$ thyroid dose limit established by the EPA. Thus, the RF goal of $10^{3}$ considered in many process designs or $\sim 250$ defined by the EPA, $5 \mathrm{mCi} /$ GWe-yr, may be excessive. An RF of 100 to 150 is sufficient to ensure safe radiation levels.

The net impact on the environment will also be small. If we assume 600 tonne/yr uranium fuel reprocessing until the year 2000, an RF of 100 would al low addition of $40 \mathrm{Ci}$ or $80 \%$ of the present environmental ${ }^{129}$ I inventory. The resulting concentrations of ${ }^{129} \mathrm{I}$ in the atmosphere and natural waters of the world would be 6 to 8 orders of magnitude below the mpc.

In addition to the volumetric dilution, isotopic dilution by the large amount of nonradioactive iodine in the environment $\left(10^{14} \mathrm{~kg}\right.$ in the ocean alone) produces an equal or greater safety factor. To reach the $75 \mathrm{mrem} / \mathrm{yr}$ thyroid dose limit would require an ${ }^{129} \mathrm{I} /{ }^{127}$ I ratio of $10^{-3}$. The above release to the year 2000, based on an RF of 100 , would lead to a ratio of $10^{-12}$. Complete release of all the iodine produced--if uniformly dispersed-would give 10-10. The "natural" (pre-1946) ratios have been estimated at $10^{-12}$ to $10^{-14}$. The presently measured environmental ratios range from a few values as high as $10^{-7}$ to about $10^{-11}$. 
Thus, the data clearly show that the answer t:0 the release question is not really how much can be released - the capacity of the environment is more than adequate - it is rather a question of how good is the dispersion.

This introduces another question: What is the fate of the fraction that is trapped in iodine recovery processes? It is essential that further release be prevented during conversion to fixation forms, interim storage, and transportation. This imposes conditions for thermal and chemical stability, leach resistance, and packaging.

However, there are no criteria by which to judge actual disposal. It appears likely that negligible release from a geologic repository can be assured (i.e., iodine is kept out of contact with water) for several thousand years. It also appears that a waste form can be clevised which, if contacted by water, will release iodine to the extent of only a few percent in $10^{3}$ years.

These times are negligible by comparison to the 16-million year half-life of ${ }^{129}$ I and thus much of the iodine in disposal sites could eventually be released and find its way to the ocean. For the long-term consequence, it may be noted that if the free world supply of uranium, estimated at $2.3 \times 10^{6}$ tonne, were fissioned in light water reactors (LWR), and all the iodine released to the ocean, the ratio ${ }^{129} \mathrm{I} /{ }^{127} \mathrm{I}$ would be about $5 \times 10^{-9}$.

Although it is probably meaningless to extrapolate human endeavor beyond a few thousand years, these rough calculations may provide some basis for storage and release criteria. Again, it should be emphasized that adequate dispersal is the key to safe management of ${ }^{129} \mathrm{I}$. It is suggested that a disposal package be adopted such that when eventually contacted by water the permitted iodine release would occur over a period of a few hundred to a few thousand years. Since this iodine will eventually find its way to the ocean, it seems logical and much safer to put it there initially.

Criteria decisions would permit more meaningful design of iodine disposal forms. At present there are few guidelines for either fixation or disposal.

There is, of course, potential for high, localized ${ }^{129}$ I concentrations. If man maintains an economy based on increased use of nuclear fission, then it may be desirable in the next century or two to consider methods of absolute 
removal of the bulk of the ${ }^{129}$ I from the environment. This is considered in the next section. 
.

$-$

-1
$-\quad 1$

$\therefore$

.

$\therefore \quad 1$ 


\subsection{DISPOSAL STRATEGY}

Disposal strategy for iodine-129 has been summarized by several authors. In addition to the work cited in the Introduction, recent papers that address the topic include Kocher (1979); Burger (1980), Evans et al. (1980); Prout et a1. (1981), Miquel et a1. (1982); and Burger, Scheele, and Wiemers (1981). Disposal methods are tabulated here with brief comments.

\subsection{DISPOSAL OF RECOVERED IODINE}

\subsubsection{Transmutation to Stable Xenon}

This is deemed impractical because of low cross section of ${ }^{129}$ I. Use of a thermal reactor would require a time greater than the reactor 1 ife.

\subsubsection{Extraterrestrial Disposal}

The method is presently too expensive and has a high risk factor. It may be a reasonable approach in the next century, following new rocket payload developments and/or other strategy decisions.

\subsubsection{Ocean Disposal}

This appears to be the most attractive option, an almost universal opinion based on engineering, economic, and radiological considerations. Critics suggest that the method may never be given international approval. However, McKay, Miquel, and White (1982) point out that disposal of 129 I can be achieved within the limits specified by the London Convention (1972).

As mentioned in Section 5.0, the ocean capacity in terms of both concentration and isotopic dilution is adequate. A rather simple requirement is that the waste form have a release rate less than the ocean mixing rate to provide dispersion. Monitoring over a period of 50 to 100 years would permit decisions regarding the development of a method such as extraterrestrial disposal.

\subsubsection{Release to Coastal Waters}

This concept, as well as that of release to the atmosphere, is discussed by White and Smith (1982). The effect is highly variable and depends upon the location. Presumably this could include release to rivers with a large water 
flow. The iodine uptake by sea organisms and the pathway to man are critical issues. This strategy may be feasible in some instances.

\subsubsection{Disposal in Rock Formations}

Boreholes in granite or basalt can be located in areas where water intrusion is very unlikely for periods of greater than $10^{4}$ years. Depending on criteria decisions, a properly encapsulated, stable iodine form sealed in such a hole may be acceptable.

If water does reach the site, slow release and dilution may still reduce the concentration to minimal values and permit the iodine to find its way to the ocean without creating a hazard. Studies on iodine retention by bedrock (Allard et al. 1979) indicate that once released, the iodine will travel at the same velocity as the ground water. In other words, bedrock does not sorb iodine or retard its migration. Eventually, in terms of the time frame for radioactive decay, it must be assumed that the iodine will be released.(a)

\subsubsection{Disposal in Clay Formations}

Essentially the same factors exist as for rock. The differences are 1) the material is predominantly reducing in nature, which would protect certain insoluble iodides such as CUI, 2) water movement is extremely slow; and 3 ) there is some adsorption of iodine by clays (Allard et al. 1980). Large clay deposits (argillaceous formations) thus may have advantages over other natural formations for iodine disposal.

\subsubsection{Disposal in Salt Caverns}

It has been argued that salt formations are ideal for iodine disposal because they are normally dry. Also, in the event of water intrusion, there will be a small isotopic dilution from the iodine content of the salt.

However, as with rock formations and clay deposits, the possibility of sudden water ingression exists, and iodine behavior cannot be predicted over extremely long periods of time.

(a) A finite probability exists that the deposit will move under a geologic plate and be permanently removed. See Section 6.3. 


\subsection{TEMPORARY STORAGE OF RECOVERED IODINE}

Although temporary or interim storage is not disposal, it is included here because it is a management option and with the present absence of guidelines or criteria, it may be the only option available.

It appears relatively easy and inexpensive to store recovered iodine with excellent security against release for short periods of time, e.g., for 50 years. When a decision is made for disposal, there is the added choice of conversion to a new waste form.

\subsection{LONG-TERM CONSIDERATIONS}

Given a steadily increasing population and concomitant power production through nuclear fission there may be more incentive to permanently dispose of ${ }^{129}$ I a century from now.

Two schemes seem viable: the first, extraterrestrial disposal, although not looked on with favor at the present level of technology, does not seem beyond safe and cost-efficient development. The second is placement of the iodine in a geological formation where, over long periods of time, it will be transported deep in the earth by subduction.

At the present time tectonics is not a sufficiently precise science that selected geologic disposal would give reasonable assurance of movement of material under a continental plate, where it would be isolated for $>10$ halflives. However, it is not unreasonable to assume that this subject will be much better understood a few decades from now. 


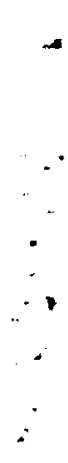




\subsection{METHODS OF FIXATION}

Given an acceptable disposal strategy it is necessary to first have the iodine immobilized in a stable, nonlabile compound. Second, it may be desirable to incorporate it in a suitable monolithic matrix. These topics have been recently reviewed by Altomare et al. (1979), Miquel et al. (1982), McKay, Miquel, and White (1982), and Burger, Scheele, and Wiemers (1981).

\subsection{FIXATION COMPOUNDS}

The fixation material may be a compound such as a metal iodide or iodate or possibly a solid sorbent such as carbon, an organic polymer, or a zeolite. The properties of fixation materials considered important are thermal stability, solubility, vapor pressure, oxidation and reduction resistance, toxicity, and cost and availability of process material. These were tabulated in the PNL report by Burger, Scheele, and Wiemers (1981) based on both experimental observations and literature data.

Of the iodides, AgI is superior on every count except cost. CuI is excellent if a reducing and nonalkaline environment can be guaranteed. However, we feel that $\mathrm{Hg}$, along with $\mathrm{Pb}$ and $\mathrm{Tl}$, should be eliminated because of their toxicity which produces a hazard at least as great as that of ${ }^{129} \mathrm{I}$.

Many iodates are acceptable, but the choices, based on current studies, are $\mathrm{Ba}, \mathrm{Sr}$, or $\mathrm{Ca}$. They are appreciably more soluble than AgI but have other desirable properties, including compatibility with oxidizing and hydrolytic conditions.

Iodine on solid sorbents has, in general, a lower level of stability than in the above compounds, but materials such as moderately loaded AgZ or $A C-6120^{\circledR}$ may be considered fixation forms .

Other options include metal oxyiodides, sodalite, and boracite. No data has been found on the properties of the naturally occurring metal oxyiodides. Sodalite was initially examined by Strachan and Babab (1979), Winters (1980), and briefly by Burger, Scheele, and Wiemers (1981). Vance et al. (1981) also briefly examined sodalite, boracite, and other mineral phases. Further investigation of minerals which can incorporate iodine would be worthwhile. 


\subsection{SOLIDIFICATION MATRICES}

For increased safety in storage and transportation, a monolithic form and/or adequate containment is necessary to maintain physical integrity. Iodine-129 is a low specific activity material, and shipping regulations refer only to such items as proper labeling and transportation by sole-use vehicles. Moderate temperature stability is desirable. A buffer material between the iodine form and the shipping drum provides additional safety.

Matrix materials considered are cement, bitumen, plastics, and glasses. Portland cement has been the most widely studied, first at ORNL (Clark 1977). The leaching of iodine compounds from cement has more recently been examined by Burger, Scheele, and Wiemers (1981) and Scheele, Burger, and Wiemers (1983). Cements are attractive because of their physical and chemical stability and their simplicity in use.

Bitumen may be a good matrix for iodine compounds as it presents a reducing atmosphere contrasted to the cement in air case. As such, it is ideal for compounds such as CuI. The storage of CuI in clay deposits has been under study in Belgium. The general application of bitumen is reviewed in an IAEA document (1970).

Glass waste forms are attractive because of physical form and chemical resistance. Several have been examined for incorporation of iodine compounds, but, to date, none have proved completely satisfactory. McKay, Miquel, and White (1982) have reviewed this work and briefly discuss fluoride glasses and halophosphate glasses studied at Rennes University (Malagani et al. 1978), and the borohalide glasses and glasses based on molybdate and tungstate arions (Minami, Katsuda, and Tanaka 1978). Problems identified are therma 1 decomposition of iodine compounds at glassmaking temperatures, low solubility of the iodine compounds, and the maintenance of the glassy state. Further studies would be worthwhile.

No work has been reported using organic polymers as waste matrices for iodine. The advantages might be short-term resistance to leaching and convenience of handling. Disadvantages would include chemical and radiation instability over very long time periods and potential fire hazards. Decisions on disposal criteria will determine how these factors will be weighted. 
Leaching studies at PNL have shown that silver iodide in cement and, potentially, iodine-containing sodalite are superior to other iodine forms tested. The cements containing barium iodate, calcium iodate, mercuric iodate, and iodine-loaded AgZ were nearly equivalent among themselves and, though inferior to AgI, may be acceptable forms with proper selection of disposal strategy. The toxicity of mercury probably eliminates mercuric iodate. 


\subsection{REFERENCES}

Allard, B., B. Torstenfelt, K. Andersson, and J. Rydberg. 1980. "Possible Retention of Iodine in the Ground." Scientific Basis for Nuclear Waste Management, 2: 673, C. J. M. Northup, ed. PTenum Press, New York.

Allard, B., J. Rydberg, H. Kipatsi, and B. Torstenfelt. 1979. "Disposal of Radioactive Waste in Granitic Bedrock" in Radioactive Waste in Geologic Storage, S. Fried, ed., ACS Symposium Series 100, American Chemical Society, Washingt on, D. C.

Altomare, P. M., M. Barbier, N. Lord, and D. Nainan. 1979. Assessment of Waste Management of Volatile Radionuclides. PB80-147754, The Mitre Corporation, McLean, Virginia.

Bray, L. A. and G. A. Richardson. 1983. Method to remove Iodine from Off-Gas Streams. BNW Invention Report No. E-546, Pacific Northwest Laboratory, Richland, Washington.

Brown, R. A., J. D. Christian, and T. R. Thomas. 1983a. Airborne Radioactive Waste Management. ENICO 1132, Exxon Nuclear Idaho Company, Idaho Falls, Idaho.

Brown, R. A., J. D. Christian, and T. R. Thomas. 1983b. Airborne Radioactive Waste Management, Reference Document ENICO 1133, Exxon Nuclear Idaho Company, Idaho Falls, Idaho.

BurgergL. L. and R. E. Burns. 1979. Technical Requirements for the Control of ${ }^{129}$ I in a Nuclear Fuels Reprocessing PTant. PNL-3186, Pacific Northwest Laboratory, Richland, Washington.

Burger, L. L. 1980. Determining Criteria for the Disposal of Iodine-129, PNL-3496, Pacific Northwest Laboratory, Richland, Washington.

Burger, L. L, and R. D. Scheele. 1982a. "Iodine Fixation Studies at the Pacific Northwest Laboratory." In Management Modes for Iodine-129, W. Hebel and G. Cottone, eds. Harwood Academic Publishers, New York

Burger, L. L. and R. D. Scheele. 1982b. Recycle of Iodine-Loaded Silver Mordenite by Hydrogen Reduction. PNL-4490, Pacific Northwest Laboratory, Richland, Washington.

Burger, L. L., R. D. Scheele, and K. D. Wiemers. 1981. Selection of a Form for Fixation of Iodine-129. PNL-4045, Pacific Northwest Laboratory, Richland, Washington.

Clark, W. E. 1977. "The Isolation of Radioiodine with Portland Cement. Part 1: Scoping Leach Studies. "Nuc. Tech. 36:215-221.

Code of Federal Regulations, Title 10, Chapt. 1, Part 20, "Standards for Radiation Protection". January 1, 1976. 
Code of Federal Regulations, Title 40, Part 190, "Environmental Radiation Protection Standards for Nuclear Power Operations," January 13, 1977.

Collard, G. E. R., D. Hennart, J. Van Dooren, and W. R. A. Goossens. 1980. "Iodine Trapping and Conditioning in the Mercurex System." In Proceedings of the 16th Air Cleaning Conference. CONF-801038, National Technical Information Service, Springfield, Virginia

Evoniuk, C.J. 1981. Purex Plant Gaseous Iodine-129 Control Capability and Process Development Requirements. RH0-CD-1400, Rockwe11 Hanford Operations, Richland, Washington.

Evans, E. G., W. E. Prout, J. T. Buckner and M. R. Buckner. 1980. Management of Radioactive Wastes Gases from the Nuclear Fuel Cycle. Volume 1 of Comparison of Alternatives, NUREG/CR-1546, Savannah River Plant and Laboratory, Aiken, South Carolina.

Furrer, J., R. Kaempffer, and J. G. Wilhelm. 1982. "Iodine Removal of Reprocessing Plants by Means of AC-6120 Absorption Material and Determination of its Leaching Resistance to Brine." In Management Modes for Iodine-129. W. Hebel and G. Coffone, eds. Harwood Academic Publishers, New York.

Henrich, E., H. Schmieder, W. Roesch, and F. Weirich. 1980. "Improved Iodine and Tritium Control in Reprocessing Plants." In Proceedings of the 16th DOE Air Cleaning Conference. CONF-801038, National Technical Information Service, Springfield, Virginia.

Henrich, E. and R. Hufner. 1980. Kr-85, C-14, and N0 Removal from Spent Fuel Dissolver Off-Gas at Atmospheric Pressure and at Reduced Off-Gas FTow, 16th DOE Air Cleaning Conference. CONF-801038, National Technical Information Service, Springfield, Virginia.

Holladay, D. W. 1979. A Literature Survey: Methods for the Removal of Iodine Species from of $\bar{f}$-Gases and Liquid Waste Streams of Nuclear Power and Fuel Reprocessing Plants with Emphasis on Solid Sorbents. ORNL/TM-6350, 0ak Ridge National Laboratory, Oak Ridge, Tennessee.

IAEA. 1970. Bitumenization of Radioactive Wastes. Technical Report Series116. International Atomic Energy Agency, Vienna, Austria.

IAEA. 1980. Radioiodine Removal in Nuclear Facilities. IAEA Technical Reports Series 201, International Atomic Energy Agency, Vienna.

IAEA. 1978. Removal, Storage, and Disposal of Gaseous Radionuclides from Airborne Effluents. IAEA Technical Reports Series 209, International Atomic Energy Agency, Vienna.

Jubin, R. T. 1982. "Organic Iodine Removal from Simulated Dissolver Off-gas Systems using Partially Exchanged Silver Mordenite." In Proceedings of the 17th Air Cleaning Conference. CONF-820833-12, National Technical

Information Service, Springfield, Virginia. 
Jubin, R. T. 1980. "Organic Iodine Removal from Simulated Dissolver Off-Gas Streams Using Silver-Exchanged Mordenite." In Proceedings of the 16th Air Cleaning Conference, CONF-801038, National Technical Information Service, Springfield, Virginia.

Jubin, R. T. 1979. A Literature Survey of Methods to Remove Iodine from OffGas Streams Using Solid Sorbents. ORNL/TM-6607, Oak Ridge National Laboratory, Oak Ridge, Tennessee.

Kocher, D. C. 1979. A Dynamic Model of the Global Iodine Cycle for Estimation of Dose to the World Population from Releases of Iodine-129 to the Environment. NUREG/CR-0701, Oak Ridge National Laboratory, Oak Ridge, Tennessee.

London Convention. 1972. International Convention on the Prevention of Marine Pollution by Dumping of Wastes and Other Matter. London, England.

Maeck, W. J., D. T. Pence, and J. H. Keller. 1968. "Highly Efficient Inorganic Adsorber for Airborne Iodine Species." In Proceedings of the 10th AEC Air Cleaning Conference. CONF-680821, National Technical Information Service, Springfield, Virginia

Mailen, J. C. and D. E. Horner. 1975. Removal of Radioiodine from Gas Streams by Electrolytic Scrubbing. ORNL-TM-5078, Oak Ridge National Laboratory, Oak Ridge, Tennessee.

Malagani, J. P., A. Wasniewski, M. Doreau, G. Robert and R. Mercier. 1978. Mat. Res. Bul1. 13:1009.

McKay, H. A. C., P. Miquel, and I. F. White. 1982. "Management Modes for Iodine-129." In Management Modes for Iodine-129. W. Hebel and G. Cottone, eds. Harwood Academic Publishers, New York.

Minami, T., T. Katsuda and M. Tanaki. 1978. J. Non. Cryst. Solids, 29:389.

Miquel, P., E. Zellner, J. Jaouen, and M. Pierlas. 1982. "Annex 2: TechnicoEconomic Evaluation of Different Schemes of Iodine Management." In Management Modes for Iodine-129. W. Hebel and G. Cottone, eds. Harwood Academic Publishers, New York.

Moore, J. G. and W. B. Howerton, 1971. LMFBR Fuel Cycle Studies Progress Report for April 1971, No. 26. ORNL/TM-3412, Oak Ridge National Laboratory, Oak Ridge, Tennessee.

Morgan, L. G., L. L. Burger, R. D. Scheele, and H. H. Van Tuyl. 1983. Invention Report E-549, "Pyrochemical Process for the Recovery of Silver from Silver-Containing Materials Used to Trap Iodine Species in Nuclear Process Off-gas Streams." Pacific Northwest Laboratory, Richland, Washington.

Murphy, L. P., B. A. Staples, and T. R. Thomas. 1977. The Development of $\mathrm{Ag}^{\circ} \mathrm{Z}$ for Bulk ${ }^{129}$ I Removal from Nuclear Fuel Reprocessing Plants and PbX for 129 I Storage. ICP-1135. Idaho National Engineering Laboratory, Idaho Falls, Idaho. 
NEA. 1980. Radiological Significance and Managenent of Tritium, Carbon-14, Krypton-85, Iodine-129 Arising from the Nuclear Fuel Cycle. Report by an NEA group of experts, Nuclear Energy Agency, orclanization for Economic Cooperation and Development.

Parker, G. B. 1979. Investigation of Air Cleanirg Processes for Removing

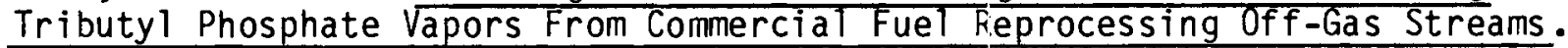
PNL-2080-18, Pacific Northwest Laboratory, Richland, Washington.

Partridge, J. A. and G. P. Bosuego. 1979. Waste Management of Mercuric Nitrate Off-Gas Scrubber Solution: A Laboratory Study. HEDL-TME 79-11, Hanford Engineering Development Laboratory, Richland, Washington.

Poulain, M. 1981. Incorporation de L'iade Dans les Verres a bas Point de fusion. Eur 7372, European Applied Research Reports, Vol. 3, Number 5. Harwood Academic Publishers, New York.

Prout, W. E., W. S. Durant, A. G. Evans, M. R. Buckner and W. V. Wright. 1981. Management of Radioactive Waste Gases from the Nuclear Fuel Cycle Vol. II, Evaluation of Storage/Disposal Alternatives. NUREG/CR-1546 DPST81-1, Vol. II, Savannah River Laboratory, Aiken, South Carolina.

Rockwell International (RHO). 1980. Purex Technical Manual, RHO MA-116, Rockwell Hanford Operations, Richland, Washington.

Rogers, G. C., J. G. Moore, and M. T. Morgan. 1980. Scrubbing of Iodine from Gas Streams with Mercuric Nitrate-Conversion of Mercuric Iodate Product to Barium lodate for Fixation in Concrete. ORNL/TM-7102. Oak Ridge National Laboratory, Oak Ridge, Tennessee.

Russel1, J. L. and P. B. Hahn. 1971. "Public Health Aspects of Iodine-129 from the Nuclear Power Industry." Radiol. Health Data Rep. 12:189.

Scheele, R. D. 1978. "Carbon-14 and Iodine-129 Fixation". Nuclear Waste Management Quarterly Progress Report April Through June 1978. A. M. P1att, J. A. Powe11, eds. PNL-2378-2, Pacific Northwest Laboratory, Richland, Washington.

Scheele, R. D. and L. L. Burger. 1981. Characterization Studies of IodineLoaded Silver Zeolites," PNL-SA-9510. Paper presented at the 182d National Meeting of the American Chemical Society, August 23-28, 1981. New York.

Scheele, R. D., L. L. Burger, and C. L. Matsuzaki. 1983. Methyl Iodide Sorption by Reduced Silver Mordenite. PNL-4489, Pacific Northwest Laboratory, Richland, Washington.

Scheele, R. D., L. L. Burger, and K. D. Wiemers. 1983. Leach Resistance of Iodine Compounds in Portland Cement." PNL-SA-10896. Paper presented at the 185th National Meeting of the American Chemical Society, March 21-25, 1983, Seattle, Washington.

Scheele, R. D. and L. L. Burger. 1982. Selection of a Carbon-14 Fixation Form. PNL-4447, Pacific Northwest Laboratory, Richland, Washington. 
Soldat, J. K. 1983. Iodine-129 Evaluation of Releases from Nuclear Power Generation, NCRP Report No. 75 .

Strachan, D. M., and H. Babab. 1979. Iodide and Iodate Sodalites for the Long-Term Storage of Iodine-129. RH0-SA-83, Rockwell Hanford Operations, Richland, Washington.

Strachan, D. M. 1978. Analysis of the Dissolver Silver Reactors from Hanford's Purex Plant. RHO-ST-2, Rockwell Hanford Operations, Richland, Washington.

Stromatt, R. W. 1958. Removal of Radioiodine from Purex Off-Gases with Nitric Acid and Nitric Acid-Mercuric Nitrate Solutions. USAEC Report HW55735, Hanford Atomic Products Operation, Richland, Washington.

Swanson, J. L. 1978. Control of Radioiodine in the Excess Water Stream of a Nuclear Fuels Reprocessing Plant. PNL-2080-9, Pacific Northwest Laboratory, Richland, Washington.

Thomas, T. R., L. P. Murphy, B. A. Staples and J. T. Nichols. 1977. Airborne Elemental Iodine Loading Capacities of Metal Zeol ites and a Method for Recycling Silver Zeolite. ICP1119, Idaho National Engineering Laboratory, Idaho Falls, ID.

Trevorrow, L., G. Vandegrift, V. Kolba, and M. Steindler. 1983. Compatibility of Technologies with Regulations in the Waste Management of $\mathrm{H}-3, \mathrm{I}-129, \mathrm{C}-14$, and $\mathrm{Kr}-85$ : Part I. Initial Information Base. ANL-83-57, Argonne National Laboratory, Argonne, Illinois.

Vance, E. R., D. K. Agrawal, B. E. Scheetz, J. G. Pepin, S. D. Atkinson, and W. B. White. 1981. Ceramic Phases for Immobilization of ${ }^{129}$ I. DOE/ET/41900-9 (ESG-DOE-13354), Pennsylvania State University Park, Pennsylvania.

White, I. F. and G. M. Smith. 1982. "Annex 1: The Radiobiological Impact of Iodine-129 Management." In Management Modes for Iodine-129. W. Hebel and G. Cottone, eds. Harwood Academic Publishers, New York.

Winters, W. I. 1980. The Effects of Hot-Pressing Conditions on the Properties of Iodine Sodalite. RHO-LD-153, Rockwell Hanford Operations, Richland, Washington.

Yarbro, 0. 0., et a1. 1969. LMFBR Fuel Cycle Studies Progress Report for September 1969, No. 7. ORNL7TM-1748, Oak Ridge National Laboratory, Oak Ridge, Tennessee. 


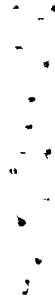


No. of

Copies

OFFSITE

27 DOE Technical Information Center

R. E. Cunningham

Office of Nuclear Safety

Materials and Safeguards

Room 562

Nuclear Regulatory Commission

7915 Eastern Avenue

Silver Springs, MD 20910

3 Division of Waste Management Nuclear Regulatory Commission Washington, DC 20555

Attn: J. B. Martin

D. B. Rohrer

R. D. Smith

Materials Section Leader

High Level Waste Licensing Branch

Nuclear Regulatory Commission

Washington, DC 20555

W. E. Mott

DOE Division of Envi ronmental

Control Technology

EV-13, GTN

Washington, DC 20545

3 DOE Office of Terminal Waste Disposal and Remedial Actions NE30, GTN

Washington, DC 20545

Attn: N. W. Ballard

F. E. Coffman

J. A. Turi

2 DOE Office of Spent Fuel

Management and Reprocessing

Systems

Washington, DC 20545

Attn: K. 0. Laughon

C. B. Bastin
No. of

Copies

3 DOE Office of Defense Waste and Byproducts Management

DP-12, GTN

Washington, DC 20545

ATTN: T. C. Chee

G. Oertel

R. D. Walton

Environmental Protection Agency

Technological Assessment

Division (AW-559)

Office of Radiation Programs

Washington, DC 20460

S. A. Mann

DOE Chicago Operations and

Regional Office

Argonne, IL 60439

J. 0 . Neff

DOE Columbus Program Office

505 King Avenue

Columbus, $\mathrm{OH} 43201$

3 DOE Idaho Operations Office

550 Second Street

Idaho Falls, ID 83401

Attn: J. P. Hamric

J. B. Whitsett

M. A. Widmayer

Office of the Assistant Manager for Energy Research and Development

DOE Oak Ridge Operations Office P. 0. Box E

Oak Ridge, TN 37830

3 DOE Savannah River Laboratory

P.0. Box A

Aiken, SC 29801

Attn: E. S. Goldberg

T. B. Hindman

R. B. Whitfield 
R. Y. Lowrey

DOE Albuquerque Operations

Office

P. 0. Box 5400

Albuquerque, NM 87185

S. G. Harbinson

DOE San Francisco Operations Office

1333 Broadway

Oakland, CA 94612

W. F. Holcomb

National Institute of Health

Radiation Safety Branch

Building 21

Bethesda, MD 20205

2 Allied-General Nuclear Services

P. 0. Box 847

Barnwel1, SC 29812

ATTN: J. A. Buckham

A. Williams

2 Argonne National Laboratory

9700 South Cass Avenue

Argonne, IL 60439

ATTN: J. H. Kittel

M. J. Steindler/

L. E. Trevorrow

10 Battelle Memorial Institute

505 King Avenue

Columbus, $\mathrm{OH} 43201$

ATTN: S. H. Basham

A. Carbiener

N. E. Carter

J. 0. Duguid

S. Goldsmith

P. L. Hofmann

M. Kehnemuyi

J. F. Kircher

B. Rawles (2)

2 EG\&G Idaho, Inc.

P. 0. Box 1625

Idaho Falls, ID 83415

ATTN: G. B. Levin

R. L. Tallman
Copies

R. Williams

Electric Power Research

Institute

3412 Hillview Avenue

P. O. Box 10412

Palo Alto, CA 94304

R. A. Brown

Exxon Nuclear Idaho

P. C. Box 2800

Idaho Falls, ID 83401

6 Oak Ridge National Laboratory

P.0. Box X

Oak Ridge, TN 37830

ATTN: J. 0. Bl omeke

W. D. Burch

A. G. Croff

R. J. Jubin

R. G. Wymer

T. G. Row

7 E. I. duPont deNemours \& Co. Inc.

Savannah River Laboratory

Aiken, SC 29801

ATTN: H. H. Baker

M. D. Boersma

J. L. Crandall

S. D. Harris

D. L. Mc Intosh

S. Mirshak

S. W. O'Rear

E. Vejvoda

Rockwell International

Rocky Flats Plant

P. O. Box 464

Golcen, CO 80401

L. H. Brooks

Gulf Energy and Environmental Systems

P. 0. Box 81608

San Diego, CA 92138

J. L. Larocca, Chairman

Energy Research and Development Authority

Empire State Plaza

Albany, NY 12223 
\begin{tabular}{l} 
No. of \\
Copies \\
\hline
\end{tabular}

2 Lawrence Livermore Laboratory

P. 0. Box 808

Livermore, CA 94550

ATTN: J. H. Campbel 1

W. G. Sutliff

3 Sandia Laboratories

Albuquerque, NM 87185

Attn: 0 . E. Jones

R. G. Kepler

W. Weart

R. Roy

202 Materials Research

Laboratory

University Park, PA 16802

J. R. Potter

Chem-Nuclear Systems, Inc.

P. 0. Box 1866

Bellevue, WA 98009

R. G. Post

College of Engineering

University of Arizona

Tucson, AZ 85721

W. A. Freeby

Bechtel Group, Inc.

Fifty Beale Street

P. 0. Box 3965

San Francisco, CA 94119

L. L. Hench

Dept. of Materials Science and Engineering

University of Florida

Gainesville, FL 32611

H. Palmour III

2140 Burlington Engineering Laboratories

North Carolina State University

Raleigh, NC 27607

W. Tope

Westinghouse Electric

Corporation

Penn Center, Building 2

Box 355

Pittsburgh, PA 15230
ONSITE

No. of

Copies

4 DOE Richland Operations Office

P. F. X. Dunigan, Jr.

H. E. Ranson

J. J. Schreiber (2)

12 Rockwell Hanford Operations

J. L. Deichman

J. 0. Honeyman

$L$. Jensen

J. E. Kinser

H. G. McGuire

J. Reser

J. H. Roecker

W. W. Schulz

R. E. Van der Cook

D. G. Wilkins

G. D. Wright

File Copy

2 UNC United Nuclear Industries

F. H. Bouse, Document Control

T. E. Dabrowski

3 Westinghouse Hanford Company

A. G. Bl asewitz

R. E. Lerch

J. J. McCown

67 Pacific Northwest Laboratory

W. F. Bonner

F. P. Brauer

L. A. Bray

L. L. Burger (15)

T. D. Chikalla

C. R. Hann

0. F. Hill

J. H. Jarrett

A. B. Johnson, Jr.

S. E. King

M. R. Kreiter

L. T. Lakey

R. C. Liikala

R. P. Marshall

E. D. McClanahan 
No. of

Copies

J. L. MCEl roy

J. E. Mendel

I. C. Nelson

J. M. Nielsen/R. W. Perkins

R. E. Nightingale

A. M. Platt

W. A. Ross

J. M. Rusin

R. D. Scheele (15)

J. K. Soldat

J. L. Swanson

G. L. Tingey

C. L. Unruh

H. H. Van Tuyl

E. C. Watson

E. J. Wheelwright

W. R. Wiley

Technical Information (5)

Publishing Coordination (2) 